Article

\title{
Comparative Proteomic Analysis during the Involvement of Nitric Oxide in Hydrogen Gas-Improved Postharvest Freshness in Cut Lilies
}

\author{
Jianqiang Huo, Dengjing Huang, Jing Zhang, Hua Fang, Bo Wang, Chunlei Wang, Zhanjun Ma \\ and Weibiao Liao * \\ College of Horticulture, Gansu Agricultural University, Lanzhou 730070, China; huojq3061@163.com (J.H.); \\ huangdj3032@163.com (D.H.); zhangj4517@163.com (J.Z.); fangh1610@163.com (H.F.); \\ wangb0447@163.com (B.W.); wangchunlei@gsau.edu.cn (C.W.); mazhanjun@gsau.edu.cn (Z.M.) \\ * Correspondence: liaowb@gsau.edu.cn; Tel.: +86-138-9328-7942
}

Received: 29 October 2018; Accepted: 6 December 2018; Published: 9 December 2018

\begin{abstract}
Our previous studies suggested that both hydrogen gas $\left(\mathrm{H}_{2}\right)$ and nitric oxide $(\mathrm{NO})$ could enhance the postharvest freshness of cut flowers. However, the crosstalk of $\mathrm{H}_{2}$ and $\mathrm{NO}$ during that process is unknown. Here, cut lilies (Lilium "Manissa") were used to investigate the relationship between $\mathrm{H}_{2}$ and $\mathrm{NO}$ and to identify differentially accumulated proteins during postharvest freshness. The results revealed that $1 \%$ hydrogen-rich water (HRW) and $150 \mu \mathrm{M}$ sodium nitroprusside (SNP) significantly extended the vase life and quality, while NO inhibitors suppressed the positive effects of HRW. Proteomics analysis found 50 differentially accumulated proteins in lilies leaves which were classified into seven functional categories. Among them, ATP synthase CF1 alpha subunit (chloroplast) (AtpA) was up-regulated by HRW and down-regulated by NO inhibitor. The expression level of LlatpA gene was consistent with the result of proteomics analysis. The positive effect of HRW and SNP on ATP synthase activity was inhibited by NO inhibitor. Meanwhile, the physiological-level analysis of chlorophyll fluorescence and photosynthetic parameters also agreed with the expression of AtpA regulated by HRW and SNP. Altogether, our results suggested that NO might be involved in $\mathrm{H}_{2}$-improved freshness of cut lilies, and AtpA protein may play important roles during that process.
\end{abstract}

Keywords: proteomic; postharvest freshness; ATP synthase; ATP synthase CF1 alpha subunit (chloroplast); chlorophyll fluorescence parameters; photosynthetic parameters

\section{Introduction}

Hydrogen gas $\left(\mathrm{H}_{2}\right)$, a colorless and odorless gas, is the lightest and structurally simplest gas in the world. As an important signaling molecule, $\mathrm{H}_{2}$ has been shown to be involved in many plant developmental processes [1]. More recently, some researchers found that $\mathrm{H}_{2}$ could alleviate aluminum (Al) toxicity [2], mercury $(\mathrm{Hg})$ toxicity [3], and UV-A irradiation [4] by increasing the activity of antioxidant enzymes. Meanwhile, $\mathrm{H}_{2}$ could promote lateral root formation through nitric oxide (NO) synthesis induced by auxin [5] or in a heme oxygenase-1/carbon monoxide-dependent manner [6]. Significantly, $\mathrm{H}_{2}$ was also reported to play an important role in delaying senescence and maturity $[7,8]$. Hydrogen-rich water (HRW) treatments could prolong the shelf life of kiwifruit by regulating the antioxidant defense [7]. Our study has shown that $\mathrm{H}_{2}$ enhanced the vase life and postharvest quality of cut lily (Lilium spp.) and cut rose (Rosa hybrid L.) flowers through maintaining water balance and membrane stability [8]. However, the deep mechanism of $\mathrm{H}_{2}$ in delaying the senescence and shelf life of perishable horticultural products needs to be further investigated.

$\mathrm{NO}$ is a signaling molecule that interacts with other hormones and growth regulators. Recently, NO was reported to play vital roles in delaying senescence and improving the quality of horticultural 
products. NO inhibited the production of ethylene by modulating the expressions of some genes and proteins during postharvest of horticulture plants [9]. NO, as a preservative solution to cut flowers, can extend the vase life of cut gerbera flowers by increasing water uptake and promoting antioxidant activity [10]. Exogenous NO could also promote the vase life of cut gladiolus flowers by increasing the scavenging mechanism of reactive oxygen species (ROS) and down-regulating the expression of senescence-associated genes (SAGs) [11]. The vase life of cut carnation flowers was significantly prolonged by exogenous $\mathrm{NO}$, which improved the activity of antioxidant enzymes including superoxide dismutase (SOD), peroxidase (POD), catalase (CAT), and ascorbate peroxidase (APX) [12]. Our previous study reported that NO could decrease ethylene production in cut roses by inhibiting the activity of 1-aminocyclopropane-1-carboxylate oxidase (ACO), thus promoting the vase life of cut roses [13].

As mentioned above, $\mathrm{H}_{2}$ and $\mathrm{NO}$ as exogenous gaseous signaling molecules played exceedingly positive roles in the postharvest preservation of horticultural products. The relationship between $\mathrm{H}_{2}$ and $\mathrm{NO}$ in plants has been reported in recent years. $\mathrm{H}_{2}$ was reported to regulate stomatal movement, which is involved in the abscisic acid (ABA) signaling cascade by promoting the generation of NO [14]. Meanwhile, Zhu et al. [15] also found that the adventitious root formation in cucumber explants induced by $\mathrm{H}_{2}$ was dependent on the $\mathrm{NO}$ pathway [15]. Furthermore, $\mathrm{H}_{2}$ could alleviate the Al-induced inhibition of alfalfa root elongation by inhibiting the production of $\mathrm{NO}$ [16]. $\mathrm{H}_{2}$ also was reported to be involved in auxin-induced lateral root formation, at least partially via a nitrate reductase (NR)-dependent NO synthesis [5]. Up to now, far too little attention has been paid to the crosstalk between $\mathrm{H}_{2}$ and $\mathrm{NO}$ during the postharvest preservation of horticultural plants. In this study, pharmacological approaches and comparative proteomic analysis were applied to investigate the roles of $\mathrm{H}_{2}$ and NO during the postharvest storage of cut lily (Lilium "Manissa") flowers and to identify the differentially accumulated proteins during that process. Thus, the study offers some important insights into the protein changes in the $\mathrm{NO}-\mathrm{H}_{2}$-regulated postharvest preservation of cut flowers.

\section{Results}

\subsection{Effects of HRW, Sodium Nitroprusside (SNP), and NO Inhibitors on Vase Life}

Compared with the control (distilled water), the vase life of cut lilies was extended by applying $150 \mu \mathrm{M}$ SNP or 1\% HRW (Figure 1). However, there was no significant difference between SNP and HRW. Compared with the HRW, $1 \% \mathrm{HRW}$ together with $50 \mu \mathrm{M} \mathrm{NaN} \mathrm{N}_{3}$ or $100 \mu \mathrm{M}$ tungstate significantly decreased vase life, indicating the involvement of NO in the HRW-enhanced vase life of cut lilies (Figure 1).

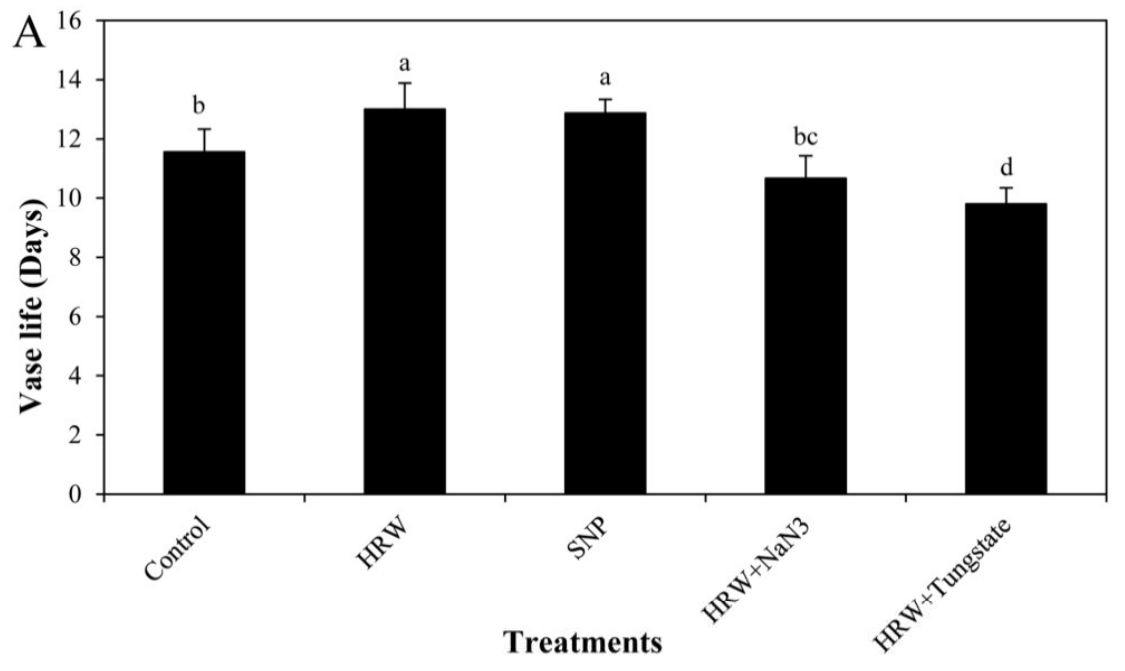

Figure 1. Cont. 
$\mathrm{B}$
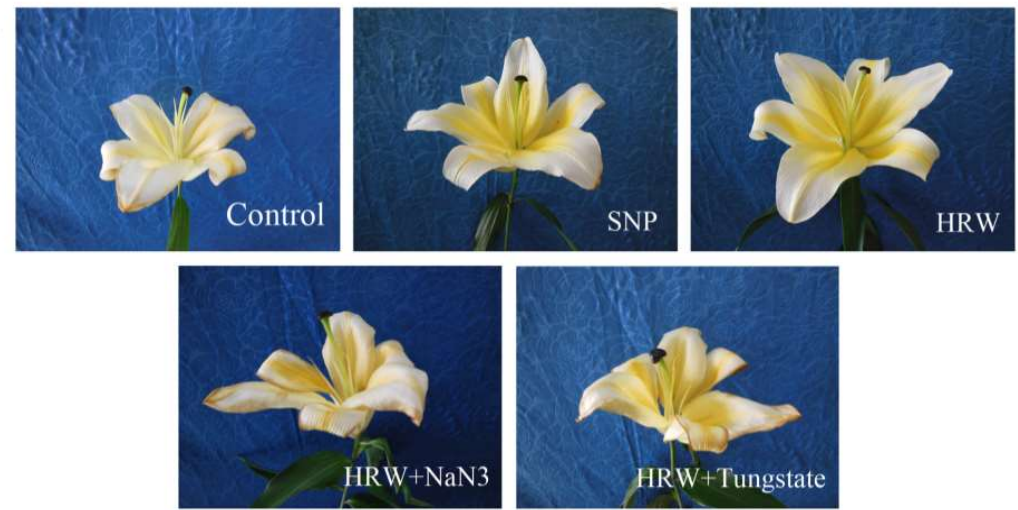

Figure 1. Effects of hydrogen-rich water (HRW), sodium nitroprusside (SNP), and HRW plus $\mathrm{NaN}_{3}$ or tungstate on the vase life of cut lily flowers. The cut flowers were placed randomly in distilled water (control), $150 \mu \mathrm{M} \mathrm{SNP}, 1 \% \mathrm{HRW}, 1 \% \mathrm{HRW}+50 \mu \mathrm{M} \mathrm{NaN} \mathrm{N}_{3}$ and $1 \% \mathrm{HRW}+100 \mu \mathrm{M}$ tungstate to investigate. The values of vase life (A) are the mean \pm SE of three independent experiments. Bars with different letters illustrate significant differences $(p<0.05)$ according to Duncan's multiple range test. Photos (B) were taken after 8 days of treatments.

\subsection{Effects of HRW, SNP, and NO Inhibitors on Maximum Flower Diameter and Rate of Fresh Weight Change}

As shown in Figure 2A, the maximum value of the maximum flower diameter in the control and SNP treatment was obtained on the sixth day. The maximum value in HRW treatment appeared at the seventh day, while when HRW was applied with $\mathrm{NaN}_{3}$ or tungstate, the maximum values were detected on the fifth day (Figure 2A). Interestingly, various vase solutions had no effects on the maximum flower diameter, suggesting that HRW merely delayed the flowering time rather than expanding the flower diameter.
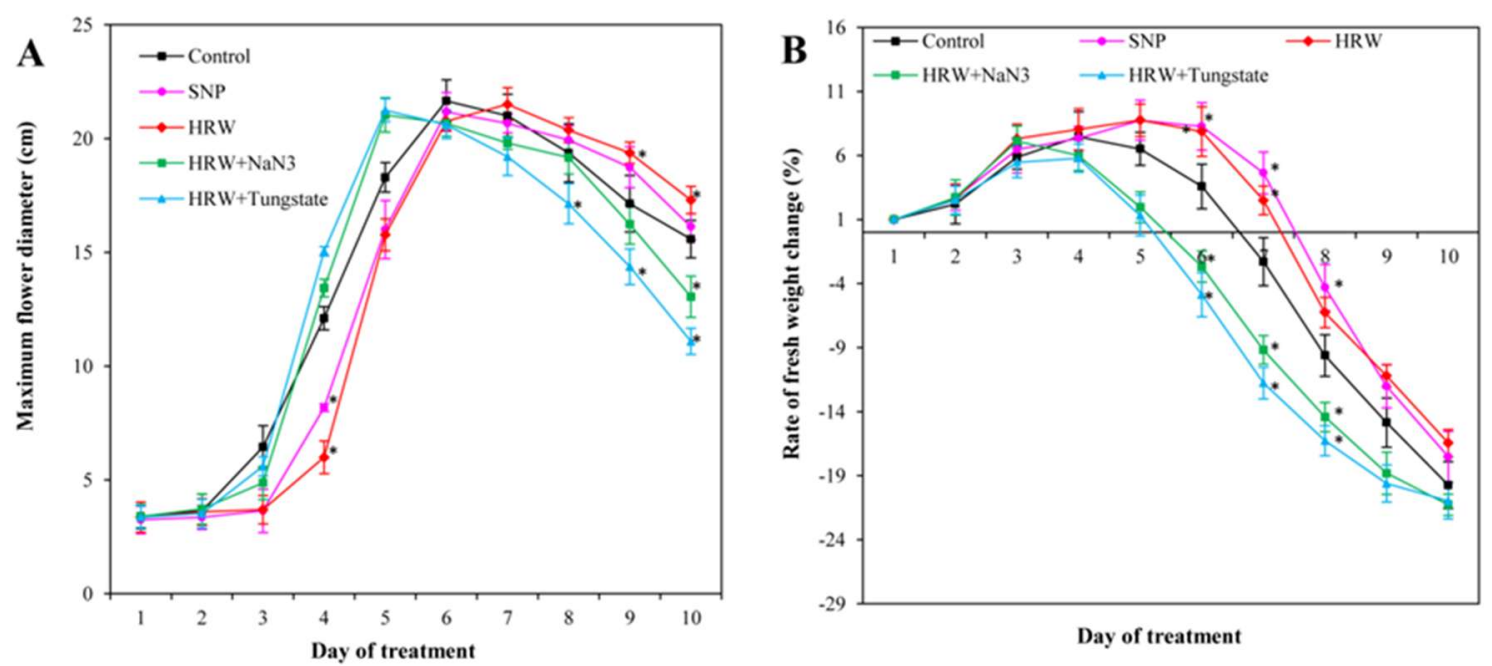

Figure 2. Effects of $\mathrm{HRW}, \mathrm{SNP}$, and $\mathrm{HRW}$ plus $\mathrm{NaN}_{3}$ or tungstate on flower diameter and fresh weight of the cut lilies. Maximum flower diameter (A) and rate of fresh weight change (B) were expressed as mean \pm SE of three independent experiments. Asterisks indicate significant difference $(p<0.05$ by Duncan's multiple range test) compared to the control within the same day.

As time passed, the rate of fresh weight change initially increased and then decreased (Figure 2B). Compared with the control, the decrease of fresh weight in HRW or SNP treatment was postponed for one day after treatment, whereas the decrease of fresh weight in HRW plus tungstate treatment significantly appeared one day in advance. The decrease of fresh weight in HRW or SNP was 
significantly lower than in $\mathrm{HRW}$ with $\mathrm{NaN}_{3}$ or tungstate (Figure 2B), indicating that the inhibition of endogenous NO could decrease the effect of HRW.

\subsection{Two-Dimensional Electrophoresis Analysis and Identification of Proteins}

In the study, the differentially accumulated proteins between control and treatments (SNP, HRW, $\mathrm{HRW}+\mathrm{NaN}_{3}$ or tungstate) were analyzed. In comparison of these two-dimensional electrophoresis (2-DE) gel images (Figure 3), 77 protein spots where the abundance was detected at ratios over 1.5 -fold and false discovery rate (FDR) less than $5 \%$ were obtained on these images to analyze their basic information and function by 2-DE coupled to MALDI-TOF/TOF-MS. From these protein spots, 50 differentially accumulated proteins were successfully identified from the NCBI and Uniprot databases by Mascot analysis (Table 1 and Table S1). The molecular weights and isoelectric points (pIs) of identified proteins presented a different degree of variation, with molecular weights ranging from $16.70 \mathrm{kDa}$ to $81.88 \mathrm{kDa}$ and with pIs ranging from 4.83 to 9.35 (Table 1). Eleven protein spots were identified in the HRW treatment, while 10 spots were identified in the SNP treatment (Figure 3 and Figure S1). However, 20 or 9 protein spots were identified in $\mathrm{HRW}$ with $\mathrm{NaN}_{3}$ or tungstate, respectively.

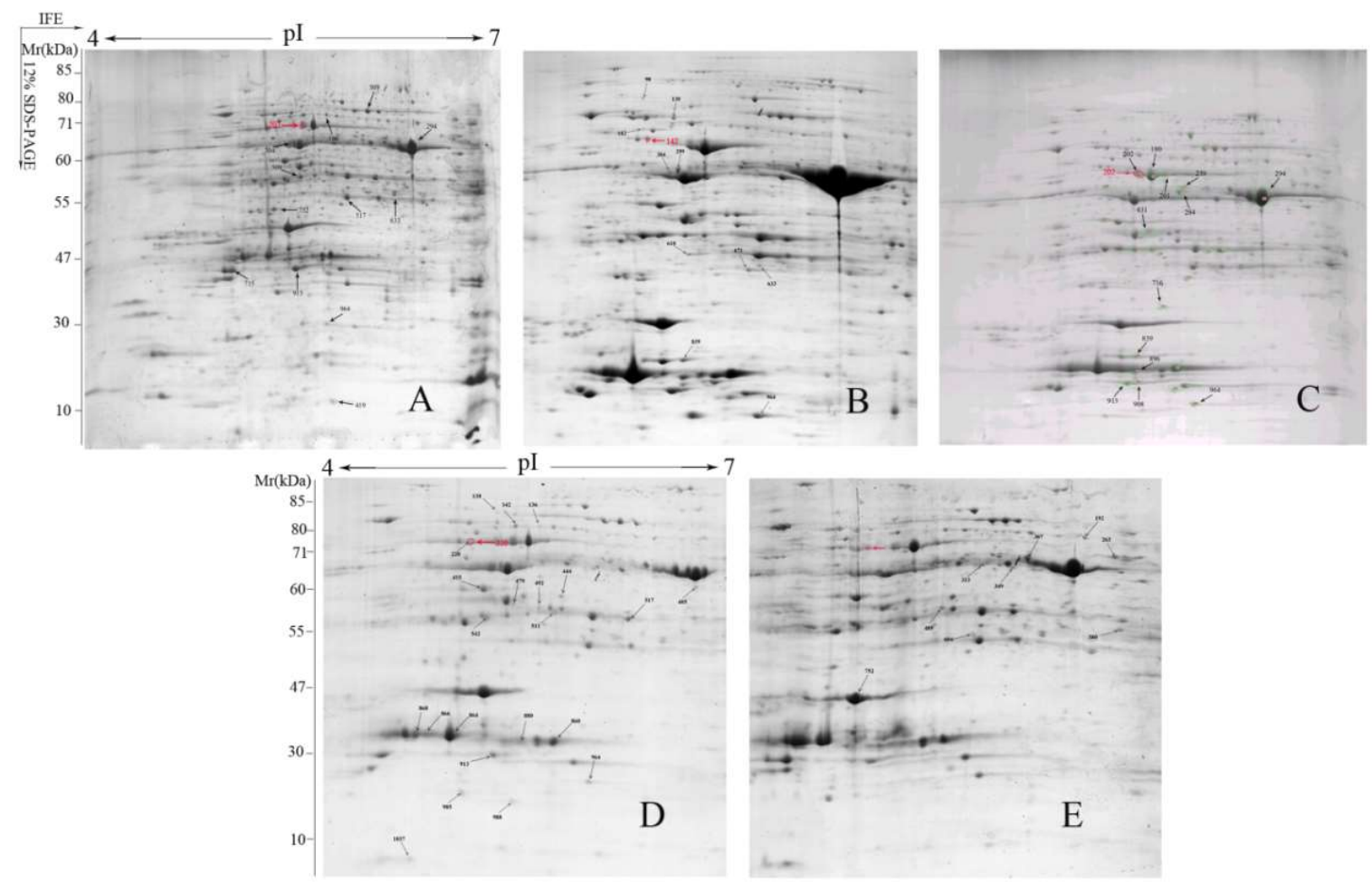

Figure 3. Two-dimensional electrophoresis (2-DE) image analysis of cut lily leaf proteins. Arrows indicate the 77 protein spots that were detected in control (A); $150 \mu \mathrm{M} \mathrm{SNP}(\mathbf{B}) ; 1 \% \mathrm{HRW}$ (C); $1 \% \mathrm{HRW}$ $+50 \mu \mathrm{M} \mathrm{NaN}_{3}$ (D); and 1\% HRW + $100 \mu \mathrm{M}$ tungstate (E). The red arrows show the spots of differentially accumulated ATP synthase CF1 alpha subunit (chloroplast) (AtpA) protein under different treatments. 
Table 1. Identification and analysis of proteins in leaves of cut lily after HRW, SNP, and HRW plus $\mathrm{NaN}_{3}$ or tungstate treatment.

\begin{tabular}{|c|c|c|c|c|c|c|c|c|c|}
\hline Spot No. & Protein Name & Species & Accession No. & $\begin{array}{c}\text { Expressed MW } \\
(\mathrm{Da}) / \mathrm{pI}\end{array}$ & $\begin{array}{l}\text { Theoretical MW } \\
\text { (Da)/pI }\end{array}$ & Peptide Count & Score & $\begin{array}{c}\text { Protein Score } \\
\text { Confidence level (C.I.\%) }\end{array}$ & Up/Down \\
\hline 201 & $\begin{array}{l}\text { ATP synthase CF1 alpha subunit } \\
\text { (chloroplast) }\end{array}$ & Lilium superbum & YP_009130198.1 & $55,285.2 / 5.41$ & $55,319.38 / 5.41$ & 21 & 962 & 100 & $\uparrow$ \\
\hline 259 & $\begin{array}{l}\text { ATP synthase alpha subunit, partial } \\
\text { (mitochondrion) }\end{array}$ & $\begin{array}{l}\text { Erythronium } \\
\text { dens-canis }\end{array}$ & AFM91753.1 & $28,195.8 / 6.51$ & $28,213.43 / 6.50$ & 10 & 114 & 100 & $\uparrow$ \\
\hline 202 & $\begin{array}{l}\text { ATP synthase CF1 alpha subunit } \\
\text { (chloroplast) }\end{array}$ & Lilium superbum & YP_009130198.1 & $55,285.2 / 5.41$ & $55,319.38 / 5.41$ & 22 & 936 & 100 & $\uparrow$ \\
\hline 908 & $\begin{array}{l}\text { Photosystem II oxygen evolving } \\
\text { complex protein } 2 \text { precursor }\end{array}$ & Fritillaria agrestis & AAC04809.1 & $28,094.2 / 8.31$ & $28,111.52 / 8.31$ & 5 & 60 & 98.435 & $\downarrow$ \\
\hline 284 & $\begin{array}{l}\text { ATP synthase CF1 beta subunit, } \\
\text { partial (plastid) }\end{array}$ & Lilium superbum & AEZ48850.1 & $53,576.9 / 5.22$ & $53,610.53 / 5.22$ & 15 & 59 & 98.118 & $\uparrow$ \\
\hline 294 & $\begin{array}{l}\text { Ribulose-1,5-bisphosphate } \\
\text { carboxulase/oxygenase large } \\
\text { subunit, partial (chloroplast) }\end{array}$ & $\begin{array}{l}\text { Heloniopsis } \\
\text { kawanoi }\end{array}$ & AIW53238.1 & $50,960.6 / 6.23$ & $50,992.85 / 6.24$ & 29 & 1180 & 100 & $\uparrow$ \\
\hline 180 & $\begin{array}{l}\text { ATP synthase CF1 alpha subunit } \\
\text { (chloroplast) }\end{array}$ & Lilium superbum & YP_009130198.1 & $55,285.2 / 5.41$ & $5319.38 / 5.41$ & 21 & 865 & 100 & $\uparrow$ \\
\hline 896 & Carbonic anhydrase & $\begin{array}{l}\text { Musa acuminata } \\
\text { subsp. }\end{array}$ & $\operatorname{Tr} \mid$ M0TL28 & 22,422.1/5.07 & $22,436.69 / 5.06$ & 4 & 104 & 99.985 & $\uparrow$ \\
\hline 716 & PDZ domain-containing protein & $\begin{array}{c}\text { Cynara } \\
\text { cardunculus var. }\end{array}$ & $\operatorname{Tr} \mid \mathrm{A} 0 \mathrm{~A} 118 \mathrm{JU} 51$ & $36,198.3 / 6.18$ & $36,220.78 / 6.18$ & 6 & 113 & 99.998 & $\uparrow$ \\
\hline 913 & $\begin{array}{l}\text { Chlorophyll a-b binding protein, } \\
\text { chloroplastic }\end{array}$ & $\begin{array}{l}\text { Musa acuminata } \\
\text { subsp. }\end{array}$ & $\operatorname{Tr} \mid$ MOSBM9 & 29,718.2/8.96 & $29,737.07 / 8.96$ & 4 & 171 & 100 & $\uparrow$ \\
\hline 431 & Actin & $\begin{array}{l}\text { Lilium davidii var. } \\
\text { Davidii }\end{array}$ & ALO18835.1 & $41,649.0 / 5.31$ & $41,675.77 / 5.31$ & 15 & 447 & 100 & $\uparrow$ \\
\hline 511 & Glutamine synthetase & Tulipa pulchella & BAM84282.1 & $38,673.4 / 5.64$ & $38,697.60 / 5.64$ & 5 & 90 & 99.999 & $\uparrow$ \\
\hline 479 & Actin & Lilium regale & AFU06383.1 & $41,619.0 / 5.31$ & $41,645.75 / 5.31$ & 16 & 421 & 100 & $\uparrow$ \\
\hline 492 & Monodehydroascorbate reductase & Lilium longiflorum & ADF43731.1 & $46,732.5 / 5.89$ & $46,761.56 / 5.89$ & 14 & 86 & 99.996 & $\uparrow$ \\
\hline 220 & $\begin{array}{l}\text { ATP synthase CF1 alpha subunit } \\
\text { (chloroplast) }\end{array}$ & Lilium superbum & YP_009130198.1 & $55,285.2 / 5.41$ & $55,319.38 / 5.41$ & 19 & 730 & 100 & $\downarrow$ \\
\hline 988 & $\begin{array}{l}\text { Ribulose-1,5-bisphosphate } \\
\text { carboxylase/oxygenase large } \\
\text { subunit, partial (chloroplast) }\end{array}$ & Gagea wilczekii & AAM29162.1 & $50,739.4 / 5.96$ & $50,771.69 / 5.96$ & 12 & 494 & 100 & $\uparrow$ \\
\hline 1060 & Pathogenesis-related protein 10 & Lilium regale & AHG94651.1 & $16,709.4 / 5.31$ & $16,719.85 / 5.31$ & 7 & 536 & 100 & $\downarrow$ \\
\hline 136 & $\begin{array}{l}\text { Ribulose-1,5-bisphosphate } \\
\text { carboxylase/oxygenase large } \\
\text { subunit, partial (chloroplast) }\end{array}$ & $\begin{array}{l}\text { Trillium } \\
\text { camschatcense }\end{array}$ & AFP48691.1 & $44,763.6 / 6.52$ & $44,792.01 / 6.53$ & 9 & 63 & 99.14 & $\uparrow$ \\
\hline 985 & $\begin{array}{l}\text { ATP synthase beta subunit, partial } \\
\text { (chloroplast) }\end{array}$ & $\begin{array}{c}\text { Fritillaria } \\
\text { acmopetala }\end{array}$ & AKG96681.1 & $51,914.1 / 5.13$ & $51,946.57 / 5.13$ & 16 & 68 & 99.774 & $\downarrow$ \\
\hline 142 & $\begin{array}{l}\text { ATP synthase CF1 alpha subunit } \\
\text { (chloroplast) }\end{array}$ & Ripogonum album & ANO45506.1 & $55,341.1 / 5.26$ & $55,375.27 / 5.26$ & 10 & 72 & 99.91 & $\downarrow$ \\
\hline 415 & Glutamine synthetase & Erythranthe guttata & $\operatorname{Tr} \mid \mathrm{A} 0 \mathrm{~A} 022 \mathrm{RZ} 30$ & $39,028.6 / 5.40$ & $39,053.05 / 5.39$ & 7 & 393 & 100 & $\downarrow$ \\
\hline 405 & $\begin{array}{l}\text { 6-Phosphogluconate } \\
\text { dehydrogenase, decarboxylating }\end{array}$ & Citrus sinensis & $\operatorname{Tr} \mid$ A0A067G3F9 & $53,519.6 / 6.38$ & $53,553.34 / 6.38$ & 13 & 437 & 100 & $\downarrow$ \\
\hline 444 & Elongation factor $\mathrm{Tu}$ & $\begin{array}{l}\text { Vigna angularis var. } \\
\text { Angularis }\end{array}$ & $\operatorname{Tr} \mid \mathrm{A} 0 \mathrm{~A} 0 \mathrm{~S} 3 \mathrm{RGB} 1$ & $52,659.2 / 6.34$ & $52,692.26 / 6.34$ & 14 & 671 & 100 & $\downarrow$ \\
\hline 868 & $\begin{array}{l}\text { Chlorophyll a-b binding protein, } \\
\text { chloroplastic }\end{array}$ & $\begin{array}{l}\text { Kalanchoe } \\
\text { fedtschenkoi }\end{array}$ & $\operatorname{Tr} \mid \mathrm{A} 0 \mathrm{~A} 089 \mathrm{WZX} 0$ & $28,226.3 / 5.15$ & $28,244.20 / 5.15$ & 7 & 195 & 100 & $\uparrow$ \\
\hline 517 & Glutamine synthetase & Lolium perenne & $\operatorname{Tr} /$ C5IW59 & $38,973.5 / 5.40$ & $38,998.03 / 5.40$ & 10 & 348 & 100 & $\downarrow$ \\
\hline
\end{tabular}


Table 1. Cont

\begin{tabular}{|c|c|c|c|c|c|c|c|c|c|}
\hline Spot No. & Protein Name & Species & Accession No. & $\begin{array}{c}\text { Expressed MW } \\
(\mathrm{Da}) / \mathrm{pI}\end{array}$ & $\begin{array}{l}\text { Theoretical MW } \\
\text { (Da)/pI }\end{array}$ & Peptide Count & Score & $\begin{array}{c}\text { Protein Score } \\
\text { Confidence level (C.I.\%) }\end{array}$ & Up/Down \\
\hline 866 & $\begin{array}{l}\text { Chlorophyll a-b binding protein, } \\
\text { chloroplastic }\end{array}$ & Carya cathayensis & $\operatorname{Tr} \mid \mathrm{Q} 1 \mathrm{KLZ3}$ & $28,296.3 / 5.15$ & $28,314.25 / 5.15$ & 5 & 101 & 99.969 & $\uparrow$ \\
\hline 880 & Beta carbonic anhydrase 3 & $\begin{array}{l}\text { Arabidopsis } \\
\text { thaliana }\end{array}$ & Sp I Q9ZUC2 & $28,810.8 / 6.54$ & $28,829.03 / 6.54$ & 6 & 94 & 99.83 & $\uparrow$ \\
\hline 864 & $\begin{array}{l}\text { Chlorophyll a-b binding protein, } \\
\text { chloroplastic }\end{array}$ & $\begin{array}{l}\text { Kalanchoe } \\
\text { fedtschenkoi }\end{array}$ & $\operatorname{Tr} \mid \mathrm{A} 0 \mathrm{~A} 089 \mathrm{WZX} 0$ & $28,226.3 / 5.15$ & $28,244.20 / 5.15$ & 10 & 294 & 100 & $\downarrow$ \\
\hline 860 & Carbonic anhydrase & Zea mays & $\operatorname{Tr} \mid \mathrm{Q} 41729$ & $71,291.9 / 8.93$ & $71,337.55 / 8.93$ & 10 & 101 & 99.969 & $\downarrow$ \\
\hline 542 & $\begin{array}{l}\text { Ribulose bisphosphate } \\
\text { carboxylase/oxygenase activase }\end{array}$ & $\begin{array}{l}\text { Medicago } \\
\text { truncatula }\end{array}$ & $\operatorname{Tr} \mid$ G7JTD2 & $52,135.9 / 5.42$ & $52,169.06 / 5.42$ & 15 & 358 & 100 & $\downarrow$ \\
\hline 1037 & Type II peroxiredoxin & $\begin{array}{l}\text { Medicago } \\
\text { truncatula }\end{array}$ & $\operatorname{Tr} \mid \mathrm{A} 0 \mathrm{~A} 072 \mathrm{U} 4 \mathrm{Q} 3$ & 25,893.6/9.35 & $25,909.84 / 9.35$ & 10 & 191 & 100 & $\downarrow$ \\
\hline 304 & $\begin{array}{l}\text { ATP synthase CF1 beta subunit, } \\
\text { partial (plastid) }\end{array}$ & Lilium superbum & AEZ48850.1 & $53,576.9 / 5.22$ & $53,610.53 / 5.22$ & 28 & 1190 & 100 & $\downarrow$ \\
\hline 964 & $\begin{array}{l}\text { Ribulose-1,5-bisphosphate } \\
\text { carboxylase/oxygenase large } \\
\text { subunit, partial (chloroplast) }\end{array}$ & $\begin{array}{l}\text { Cardiocrinum } \\
\text { giganteum var. } \\
\text { Yunnanense }\end{array}$ & AAM29161.1 & $50,201.1 / 6.04$ & $50,233.05 / 6.04$ & 12 & 88 & 99.998 & $\uparrow$ \\
\hline 299 & $\begin{array}{l}\text { ATP synthase CF1 beta subunit, } \\
\text { partial (plastid) }\end{array}$ & Lilium superbum & AEZ48850.1 & $53,576.9 / 5.22$ & $53,610.53 / 5.22$ & 21 & 112 & 100 & $\downarrow$ \\
\hline 130 & $70 \mathrm{kDa}$ heat shock protein & $\begin{array}{l}\text { Sandersonia } \\
\text { aurantiaca }\end{array}$ & AAL85887.1 & $36,768.6 / 4.83$ & $36,791.57 / 4.82$ & 3 & 260 & 100 & $\downarrow$ \\
\hline 633 & $\begin{array}{l}\text { NADP-dependent alkenal double } \\
\text { bond reductase P2 }\end{array}$ & Morus notabilis & Tr I W9SE47 & $40,693.7 / 6.23$ & $40,719.76 / 6.22$ & 7 & 96 & 99.89 & $\downarrow$ \\
\hline 90 & Elongation factor $\mathrm{G}$, mitochondrial & $\begin{array}{l}\text { Medicago } \\
\text { truncatula }\end{array}$ & $\operatorname{Tr} \mid$ A0A072UPP0 & $81,881.8 / 5.50$ & $81,933.70 / 5.50$ & 17 & 579 & 100 & $\downarrow$ \\
\hline 671 & Cysteine synthase & Populus trichocarpa & $\operatorname{Tr} \mid$ B9HJY5 & $34,176.2 / 7.64$ & $34,197.70 / 7.64$ & 11 & 132 & 100 & $\uparrow$ \\
\hline 839 & $\begin{array}{l}\text { Putative L-ascorbate peroxidase 2, } \\
\text { cytosolic-like }\end{array}$ & Solanum chacoense & Tr $\mid$ A0A0V0HVQ3 & $28,638.6 / 5.75$ & $28,656.76 / 5.75$ & 9 & 324 & 100 & $\uparrow$ \\
\hline 618 & Trypsin-like serine protease & $\begin{array}{l}\text { Medicago } \\
\text { truncatula }\end{array}$ & Tr I G7KIR6 & $45,774.3 / 6.79$ & $45,802.44 / 6.80$ & 10 & 525 & 100 & $\uparrow$ \\
\hline 182 & FtsH-like protein Pftf & Nicotiana tabacum & $\operatorname{Tr} \mid \mathrm{Q} 9 \mathrm{ZP} 50$ & $74,335.8 / 6.00$ & $74,382.14 / 6.00$ & 24 & 658 & 100 & $\uparrow$ \\
\hline 307 & $\begin{array}{l}\text { ATP synthase alpha subunit, partial } \\
\text { (mitochondrion) }\end{array}$ & Lilium lancifolium & AAR28047.1 & $41,824.8 / 6.47$ & $41,850.81 / 6.47$ & 13 & 397 & 100 & $\uparrow$ \\
\hline 313 & Atpb (chloroplast) & Lilium distichum & AMT85217.1 & $53,546.9 / 5.22$ & $53,580.50 / 5.22$ & 17 & 113 & 100 & $\downarrow$ \\
\hline 580 & $\begin{array}{l}\text { Glyceraldehyde-3-phosphate } \\
\text { dehydrogenase, partial }\end{array}$ & Lilium regale & AHZ94971.1 & $36,779.2 / 7.11$ & $36,802.04 / 7.11$ & 12 & 255 & 100 & $\uparrow$ \\
\hline 349 & $\begin{array}{l}\text { Ribulose-1,5-bisphosphate } \\
\text { carboxylase/oxygenase large } \\
\text { subunit, partial (chloroplast) }\end{array}$ & $\begin{array}{l}\text { Cardiocrinum } \\
\text { giganteum var. } \\
\text { Yunnanense }\end{array}$ & AAM29161.1 & $50,201.1 / 6.04$ & $50,233.05 / 6.04$ & 19 & 159 & 100 & $\uparrow$ \\
\hline 489 & Monodehydroascorbate reductase & Lilium longiflorum & ADF43731.1 & $46,732.5 / 5.89$ & $46,761.56 / 5.89$ & 18 & 271 & 100 & $\downarrow$ \\
\hline 752 & $\begin{array}{l}\text { Photosystem II oxygen evolving } \\
\text { complex protein } 1 \text { precursor }\end{array}$ & Fritillaria agrestis & AAC04808.1 & $34,847.8 / 6.26$ & $34,869.39 / 6.25$ & 16 & 695 & 100 & $\downarrow$ \\
\hline $\begin{array}{l}263 \\
192\end{array}$ & $\begin{array}{l}\text { Dihydrolipoyl dehydrogenase } \\
\text { Malic enzyme }\end{array}$ & $\begin{array}{l}\text { Salvia miltiorrhiza } \\
\text { Phaseolus angularis }\end{array}$ & $\begin{array}{l}\operatorname{Tr} \mid \text { A0A0G2SJN7 } \\
\operatorname{Tr} \mid \text { A0A0L9UG31 }\end{array}$ & $\begin{array}{c}53,520 / 6.96 \\
73,189.2 / 8.33\end{array}$ & $\begin{array}{l}53,553.72 / 6.96 \\
73,235.49 / 8.33\end{array}$ & $\begin{array}{l}6 \\
9\end{array}$ & $\begin{array}{l}259 \\
177\end{array}$ & $\begin{array}{l}100 \\
100\end{array}$ & $\uparrow$ \\
\hline 604 & Fructose-bisphosphate aldolase & $\begin{array}{c}\text { Oxytropis } \\
\text { ochrocephala }\end{array}$ & Tr । A0A0K1JSG5 & $42,894.2 / 6.39$ & $42,920.76 / 6.39$ & 9 & 477 & 100 & $\uparrow$ \\
\hline
\end{tabular}

Note: Assigned spot number as indicated in Figure 3. Arrows indicate up- $(\uparrow)$ and down- $(\downarrow)$ regulation of the proteins. 


\subsection{Functional Classification and Analysis of Differentially Accumulated Proteins}

These differentially accumulated proteins were analyzed in order to classify them in terms of their biological functions according to Gene Ontology and UniProt Protein Knowledgebase. The 50 differentially accumulated proteins identified in this study were classified into seven functional categories, as shown in below: photosynthesis ( $40 \%)$, energy metabolism $(26 \%)$, defense-related protein $(16 \%)$, amino acid metabolism (8\%), transcription and translation (4\%), cytoskeleton (4\%), and signal transduction (2\%) (Figure 4A). Subsequently, the differentially accumulated proteins among HRW, SNP, $\mathrm{HRW}+\mathrm{NaN}_{3}$, and HRW + tungstate treatments were analyzed. In HRW treatment, some differentially accumulated proteins that were associated with photosynthesis were detected, and many of them were increased when compared with the control. Among them, ATP synthase CF1 alpha subunit (chloroplast) (AtpA) was identified with three spots (180, 201, and 202), and all were up-regulated (Table 1). Under the SNP treatment, differentially accumulated proteins including FtsH-like protein Pftf (spot 182), trypsin-like serine protease (spot 618), and putative L-ascorbate peroxidase 2, cytosolic-like (spot 839) were observed. The expression of these three proteins related to defense was higher than that of the control. In HRW $+\mathrm{NaN}_{3}$ treatment, two spots were identified as AtpA, and they were down-regulated when compared with the control. The expression of proteins related with defense was significantly decreased, such as Type II peroxiredoxin (spot 1037) and pathogenesis-related protein 10 (spot 1060). Under the treatment with HRW plus tungstate, photosystem II oxygen evolving complex protein 1 precursor (spot 752) belonged to photosynthesis, and malic enzyme (spot 192) associated with energy metabolism were all down-regulated in comparison with the control (Table 1). There were four differentially accumulated proteins overlapping between $\mathrm{HRW}$ and $\mathrm{HRW}+\mathrm{NaN}_{3}$ (Figure 4B). After statistical analysis, 28 proteins in total were up-regulated while 22 proteins were down-regulated (Table 1). Among them, the number of up-regulated proteins was significantly higher in HRW than in $\mathrm{HRW}+\mathrm{NaN}_{3}$ or tungstate (Figure $4 \mathrm{C}$ ). However, the number of down-regulated proteins was lower in $\mathrm{HRW}$ than in $\mathrm{HRW}+\mathrm{NaN}_{3}$ or tungstate (Figure 4C). Thus, exogenous $\mathrm{H}_{2}$ could up-regulated some proteins during postharvest storage of cut lilies.

A

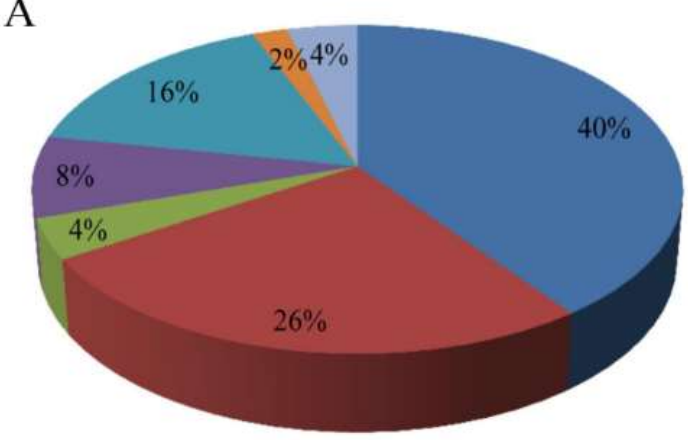

Photosynthesis

Energy Metabolism

- Transcription and Translation

- Amino acid metabolism

Defense related protein

- Signal Transduction

- Cytoskeleton

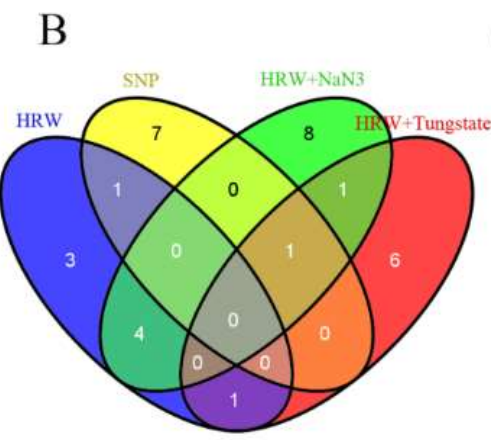

$\mathrm{C}$

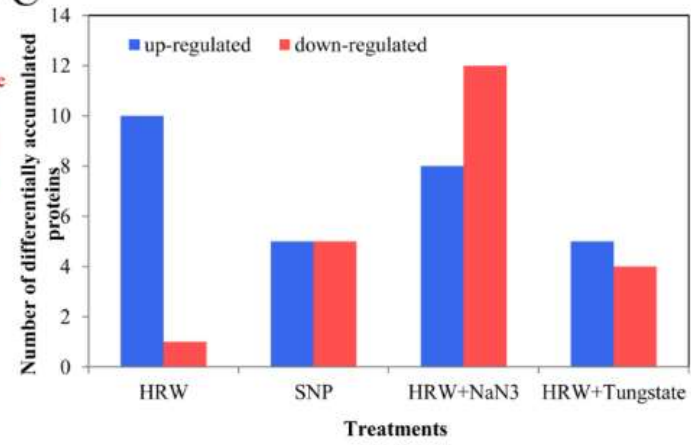

Figure 4. Cont. 


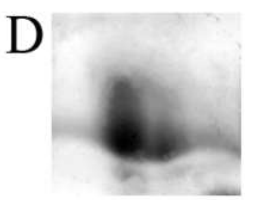

Control

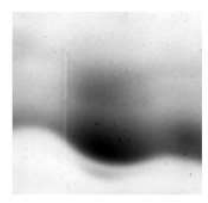

HRW

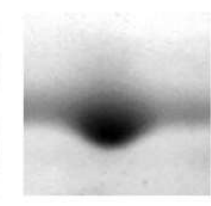

SNP

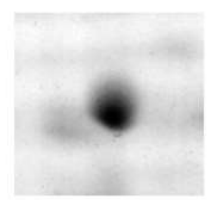

$\mathrm{HRW}+\mathrm{NaN} 3$

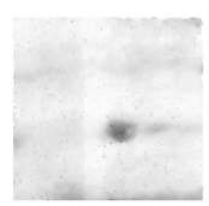

HRW+Tungstate

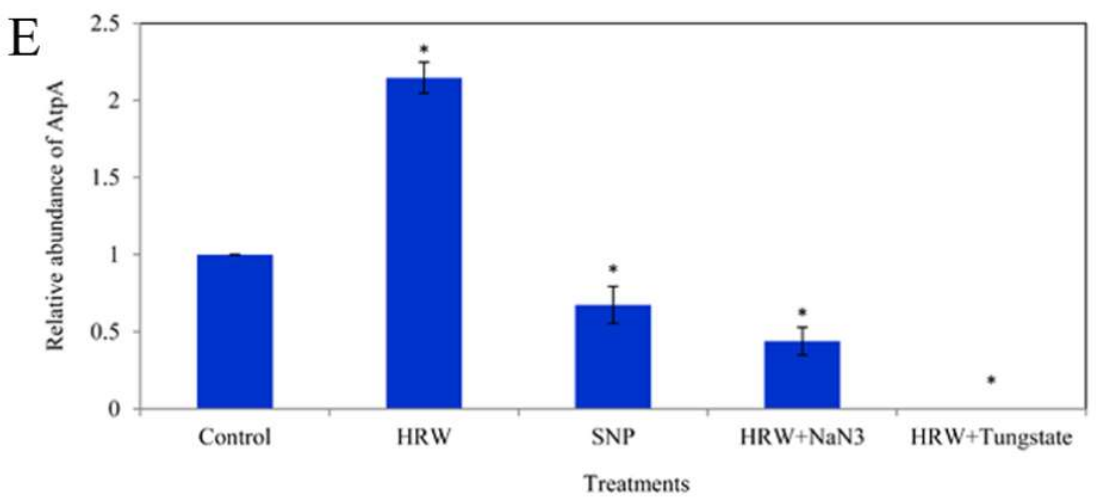

Figure 4. Functional classification and analysis of differentially accumulated proteins in cut lilies. Pie chart showed percentage of differentially accumulated proteins in different functional categories (A); Venn diagram showed the number of overlap proteins regulated by HRW, SNP, $\mathrm{HRW}+\mathrm{NaN}_{3}$ or tungstate compared with the control (B); Column chart showed the number of up- or down-regulated proteins in comparison with the control (C); The 2-DE gel sections showed the magnified views of differentially accumulated spots of AtpA protein in treatments. Spot positions corresponding to AtpA protein were shown with red arrows in Figure 2 (D); The column chart showed the differential relative abundance patterns among HRW, SNP, $\mathrm{HRW}+\mathrm{NaN}_{3}$ and $\mathrm{HRW}+$ tungstate treatment (E).

Interestingly, among them, only AtpA was up-regulated in HRW treatment and down-regulated in the HRW with $\mathrm{NaN}_{3}$ treatment. Therefore, AtpA was selected to further investigate. The magnified views of 2-DE image showed the differential accumulation of AtpA protein in treatments of the control, $\mathrm{HRW}, \mathrm{HRW}+\mathrm{NaN}_{3}$ and $\mathrm{HRW}+$ tungstate (Figure 4D). The relative abundance of AtpA protein has significant difference in 4 treatments (Figure $4 \mathrm{E}$ ). The relative abundance of AtpA in HRW treatment was significantly higher than that in the control, while the relative abundance of AtpA was less in SNP than in the control. However, the relative abundance of AtpA protein in $\mathrm{HRW}+\mathrm{NaN}_{3}$ treatment was significantly less than that in HRW treatment, and the relative abundance of AtpA was not detected in HRW + tungstate (Figure 4E), which may be caused by too low differential accumulation of AtpA in $\mathrm{HRW}+$ tungstate. Taken together, $\mathrm{H}_{2}$ could enhance the expression of AtpA protein, and the inhibitors of $\mathrm{NO}\left(\mathrm{NaN}_{3}\right.$ and tungstate) may have inhibited the effect of $\mathrm{H}_{2}$ on the expression of AtpA protein.

\subsection{Relative Expression of LlatpA Gene and the Activity of ATP Synthase (ATPase)}

The qRT-PCR analysis revealed that the relative expression of the LlatpA gene was significantly higher in HRW treatment than in the control (Figure 5). There was no significant difference in the gene expression between the control and SNP treatment. In comparison with HRW treatment, the relative expression of LlatpA gene was significantly inhabited by HRW plus $\mathrm{NaN}_{3}$ or tungstate. As shown in Figure 5, compared with control, the activity of ATPase was remarkably enhanced by SNP or HRW. However, the activity of ATPase in HRW plus $\mathrm{NaN}_{3}$ or tungstate treatment was decreased in comparison with HRW treatment.

\subsection{Chlorophyll Fluorescence and Photosynthetic Parameters}

The chlorophyll fluorescence parameters analysis result is shown in Figure 6. After 6 days of treatment, the maximum quantum yield of photosystem II complex (PSII) photochemistry (Fv/Fm) in HRW or SNP groups was higher than that in the control, whereas HRW in combination with $\mathrm{NaN}_{3}$ 
or tungstate significantly inhibited the positive effects of HRW (Figure 6A,B). After treatment for 6 days, when compared with the control, the effective quantum yield of PSII (ФPSII) and photochemical quenching (qP) were increased in HRW treatment. However, significantly decreased $\Phi P S I I$ and qP appeared in the SNP treatment group. ФPSII and qP in HRW plus $\mathrm{NaN}_{3}$ or tungstate treatment were significantly decreased in comparison with those in the HRW treatment (Figure 6C,D).

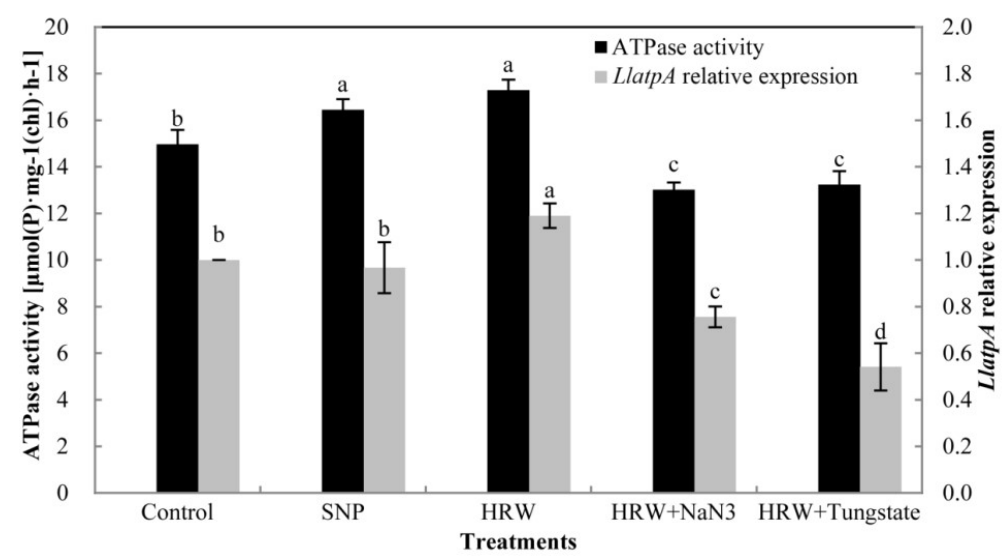

Figure 5. Effects of SNP, HRW, and HRW in combination with $\mathrm{NaN}_{3}$ or tungstate on LlatpA gene expression and ATP synthase (ATPase) activity. Values of relative expression of LlatpA gene and activity of ATP synthase are the mean \pm SE of three independent experiments with three repeats for each. Bars with different letters illustrate significant differences $(p<0.05)$ according to Duncan's multiple range test.
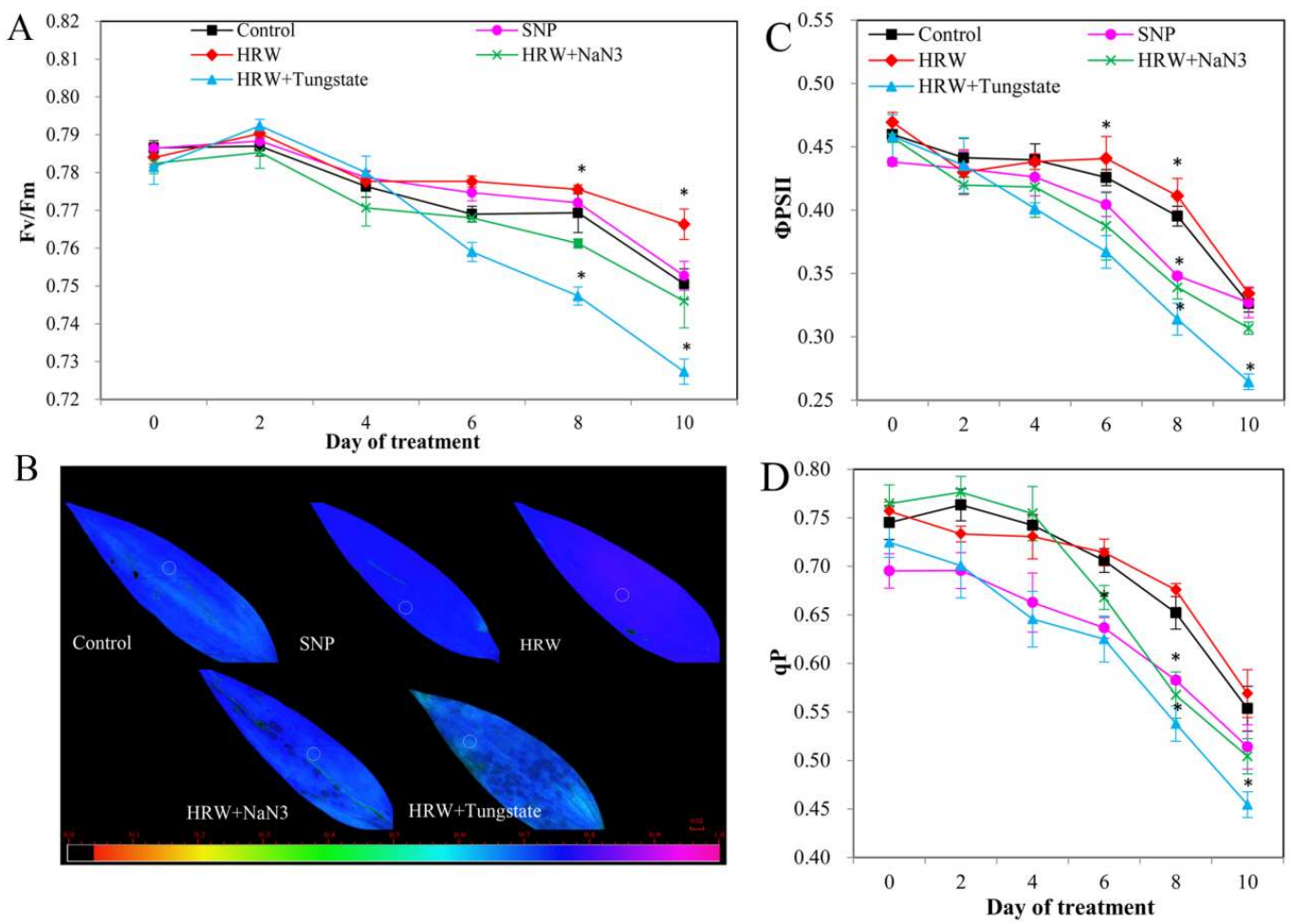

Figure 6. Effects of HRW, SNP, and HRW plus $\mathrm{NaN}_{3}$ or tungstate on chlorophyll fluorescence parameters. Values of the Fv/Fm (maximum quantum yield of PSII photochemistry) (A); effective quantum yield of PSII (ФPSII) (C); and photochemical quenching (qP) (D) are the mean \pm SE of three independent experiments with three repeats for each. Fluorescent images (B) are given in colors that represent the absolute values of the ratio ranging from 0 (black) to 1.0 (purple) and were taken on the 8 th day of treatment. Asterisks indicate significant difference $(p<0.05$ by Duncan's multiple range test) compared to the control within the same day. 
A downward trend was also observed in the net photosynthesis rate (Pn; Figure 7A) and stomatal conductance (Gs; Figure 7B) after 6 days of treatment. In contrast, intercellular $\mathrm{CO}_{2}$ concentration (Ci; Figure 7C) was slightly increased after treatment for 6 days. Transpiration rate (Tr) showed a tendency to decrease during the experiment (Figure 7D). Pn, Gs, and Tr were significantly increased by HRW or SNP in comparison with those in the control group. HRW plus $\mathrm{NaN}_{3}$ or tungstate treatment significantly decreased Pn, Gs, and Tr when compared with HRW treatment (Figure 7A,B,D). Interestingly, $\mathrm{Ci}$ in HRW treatment was lower than that in the control, whereas $\mathrm{Ci}$ in HRW together with $\mathrm{NaN}_{3}$ or tungstate treatment was higher than that in HRW treatment (Figure 7C).
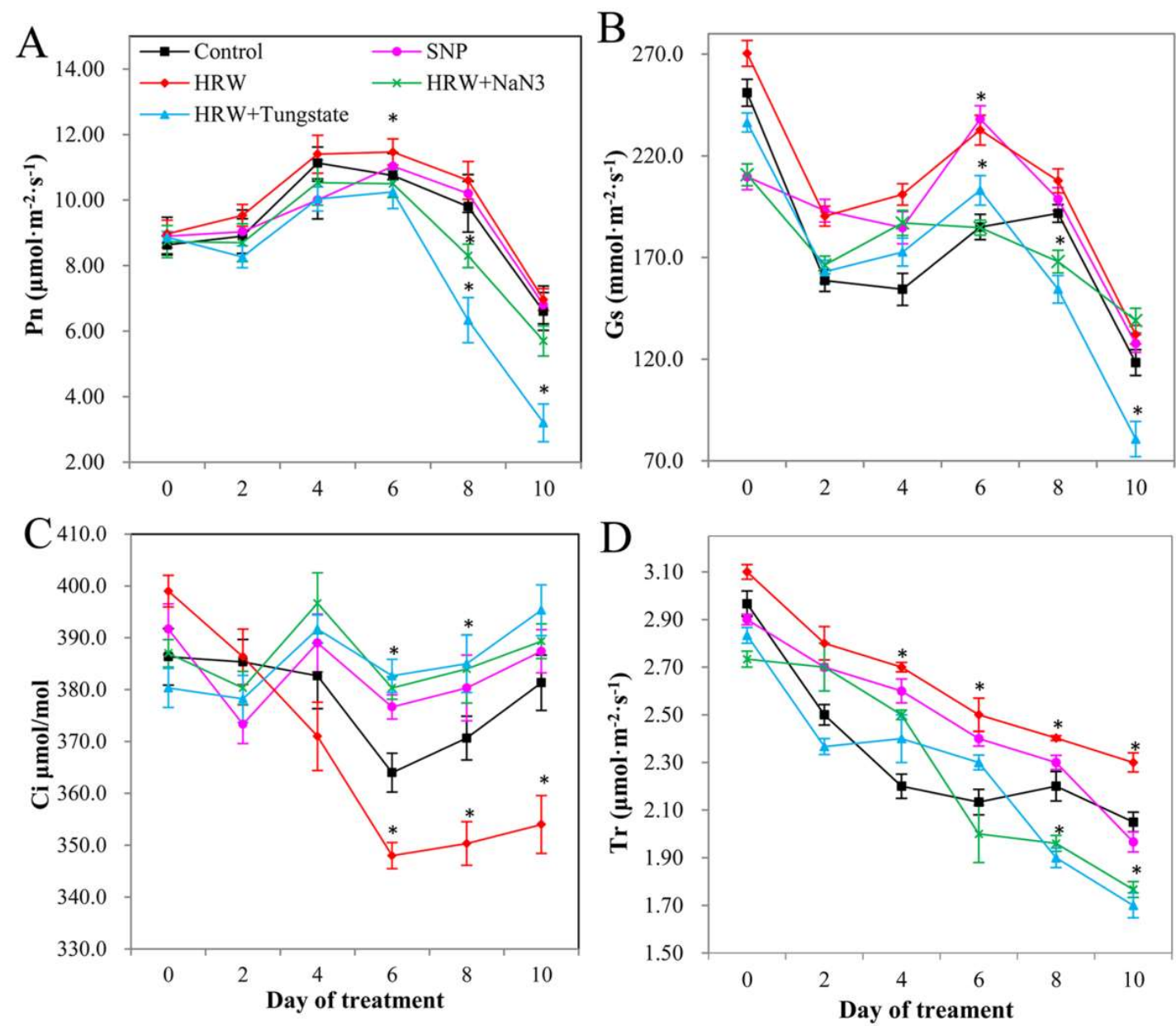

Figure 7. Effects of HRW, SNP, and $\mathrm{HRW}$ plus $\mathrm{NaN}_{3}$ or tungstate on photosynthetic parameters. Values of net photosynthetic rate (Pn) (A), stomatal conductance $(\mathrm{Gs})(\mathbf{B})$, the intercellular $\mathrm{CO}_{2}$ concentration (Ci) (C), and transpiration rate (Tr) (D) are the mean \pm SE of three independent experiments with three repeats for each. Asterisks indicate significant difference ( $p<0.05$ by Duncan's multiple range test) compared to the control within the same day.

\section{Discussion}

$\mathrm{H}_{2}$ is considered as a novel signaling molecule involved in plant developmental and physiological processes [17]. Our previous studies showed that exogenous $\mathrm{H}_{2}$ could enhance adventitious root development in marigold [18]. In addition, the shelf life of kiwifruit was prolonged by $\mathrm{H}_{2}$ by decreasing ethylene biosynthesis [19] and reducing oxidative damage [7]. In this study, $\mathrm{H}_{2}$ delayed the flowering time of cut lilies in the preservation process. $\mathrm{H}_{2}$ improved the vase life of cut lilies by maintaining the fresh weight of cut lilies. The results were consistent with those of Ren et al. (2017) [8], who showed that exogenous $\mathrm{H}_{2}$ enhanced the vase life of cut flowers by maintaining suitable water balance. In the current study, the vase life of cut lily was also enhanced by SNP treatment, suggesting that 
exogenous NO may play an important role in extending vase life. The vase life of cut gerbera was significantly extended by exogenous NO [10]. Exogenous NO also could delay petal wilting in cut carnation flowers by maintaining water metabolism and antioxidant enzyme activity [12]. In our study, $\mathrm{NaH}_{3}$ and tungstate-inhibitors of nitrate reductase (NR) that can inhibit the reduction of nitrate to nitrite and further inhibit the production of $\mathrm{NO}$-were used to investigate whether $\mathrm{NO}$ participates in $\mathrm{H}_{2}$-regulated postharvest preservation. $\mathrm{NO}$ inhibitors $\mathrm{NaN}_{3}$ or tungstate depressed the positive effects of $\mathrm{H}_{2}$ on the vase life, the maximum flower diameter, and fresh weight of cut lilies, suggesting that $\mathrm{NO}$ played vital roles in $\mathrm{H}_{2}$-induced cut flowers freshness. Our previous studies revealed that $\mathrm{H}_{2}$ increased NO generation through regulated NR and NOS activity to induce the formation of adventitious root in cucumber [20]. $\mathrm{H}_{2}$, as a mediator, activated cell cycle by $\mathrm{NO}$ pathway during adventitious root formation [15]. Additionally, $\mathrm{H}_{2}$ was also involved in auxin-induced lateral root formation via an NR-dependent NO synthesis [5]. Here, for the first time, the involvement of NO in hydrogen gas-improved vase life in cut flowers was reported.

Two-dimensional electrophoresis (2-DE)-based proteomics analysis has been applied in plant proteomic research. Here, the results of the comparative proteomic analysis showed that 50 differentially accumulated proteins were successfully identified by Mascot analysis in cut lily leaves. Among them, 28 proteins were up-regulated while 22 proteins were down-regulated. Exogenous $\mathrm{H}_{2}$ could increase the number of up-regulated proteins, while inhibitors of NO increased the number of down-regulated proteins. In chrysanthemum cuttings during adventitious root formation, 42 differentially accumulated protein spots were successfully matched to NCBI database entries [21]. In cut rose flowers, 103 proteins were obtained, and these proteins were involved in plant growth regulators, natural resistance, protein metabolism, and methionine synthesis [22]. In the current study, the 50 differentially accumulated proteins were involved in photosynthesis, energy metabolism, defense, amino acid metabolism, etc. In a Medicago sativa cadmium resistance study, the proteins related to photosynthesis were not detected in $\mathrm{H}_{2}$ treatment [23]. However, we found that the proteins involved in photosynthesis showed a high expression level in $\mathrm{H}_{2}$ treatment. This may be caused by different experimental materials and conditions. The proteins related to the stress response and defense changed significantly after NO treatment in the processes of peach fruit ripening, such as glutathione S-transferase (GST) and ascorbate peroxidase (APX) [24]. Simultaneously, we found that the expression of proteins associated with defense were up-regulated by exogenous $\mathrm{NO}$ in the cut lilies during preservation. This suggested that NO could promote the expression of proteins related to defense. The proteins related to energy metabolism were decreased during strawberry fruit ripening [25]. In litchi pulp, malate dehydrogenase (related to energy metabolism) was down-regulated in the later storage period [26]. In this study, the proteins related to energy metabolism were down-regulated in HRW plus tungstate, suggesting that NO played an important role in the proteins' expression, regulated by $\mathrm{H}_{2}$. Thus, $\mathrm{H}_{2}$ and NO could regulate the expression of proteins related to photosynthesis, defense, and energy metabolism while delaying the senescence of cut lilies.

ATP synthase CF1 alpha subunit (AtpA) protein is a key enzyme for the chloroplast thylakoid membranes, and plays a vital role in synthesizing ATP from ADP and phosphate [27]. ATP synthase CF1 $\alpha$-subunit was obtained and showed an initial increase and then a decrease in Kandelia candel under salt stress [28]. The expression of ATP synthase CF1 $\alpha$-subunit was decreased in the treatment of MAP kinase kinase (MEK) inhibitor in Chlamydomonas reinhardtii [29]. In this study, we revealed that the differential relative abundance of AtpA protein was significantly different between experimental treatments. $\mathrm{H}_{2}$ could up-regulate the expression of AtpA protein during postharvest freshness of cut lilies, while the accumulation of AtpA protein was not significantly up-regulated by NO. Interestingly, AtpA protein was down-regulated in $\mathrm{HRW}+\mathrm{NaN}_{3}$, but no accumulation spots of AtpA protein were detected in HRW + tungstate treatment. This may be because the expression of AtpA was too low (abundance $\leq 1.5$-fold) to detect in the HRW + tungstate group. This suggested that the positive effect of $\mathrm{H}_{2}$ on the expression of AtpA protein was inhibited by the inhibitors of NO. The positive roles of $\mathrm{H}_{2}$ on polyphenol oxidase activity were impaired by cPTIO (NO scavenger), L-NAME (NO synthase 
enzyme inhibitor), and $\mathrm{NaN}_{3}$ [22]. $\mathrm{H}_{2}$-promoted $\mathrm{NO}$ accumulation and stomata closure were greatly prevented by L-NAME or tungstate [14]. The above results suggest that the positive effects of $\mathrm{H}_{2}$ were reversed when the generation of $\mathrm{NO}$ was blocked by an inhibitor or scavenger. Thus, it may be that $\mathrm{H}_{2}$ at least partially played its positive roles through endogenous NO. In the study, the relative expression of LlatpA gene and the activity of ATPase were determined in order to further investigate the expression of AtpA protein at the transcriptional and biochemical levels. ATPase is embedded in the same coupling membrane, and is composed of several subunits, including an alpha subunit. The a-subunit is composed of five transmembrane helices (TMHs), including a four-helix bundle [30]. The prerequisite of ATPase exerting its proton-driven role is intersubunit mobility. Thus, the CF1 a-subunit plays an important role in ATPase. Additionally, ATPase is a key thylakoid membrane protein encoded by the atpA gene of the chloroplast genome [31]. In our study, the RT-qPCR results showed that exogenous $\mathrm{H}_{2}$ could increase the expression of the LlatpA gene. The expression of the atp $A$ gene of cucumber was increased by exogenous putrescine in salt stress [32]. $\mathrm{H}_{2}$ could get into soluble spinach chloroplast to activate ATPase by exchanging into internal parts of the molecule on energized membranes [33]. Simultaneously, the change in the expression of the atp $A$ gene was positively related to ATPase activity at the transcriptional level under low temperature conditions [34]. Meanwhile, we revealed that the activity of ATPase was also promoted by $\mathrm{H}_{2}$, which was positively related to the relative expression of the LlatpA gene. In another study, NO was found to play a vital role in stimulating $\mathrm{H}^{+}$-ATPase activity during the early stages of maize lateral root development [35]. Exogenous NO could alleviate the inhibition of $\mathrm{H}^{+}$-ATPase in plasma membrane or tonoplast which was induced by $\mathrm{CuCl}_{2}$ [36]. In the present study, exogenous $\mathrm{NO}$ could also enhance the activity of ATPase. However, the positive effects of $\mathrm{H}_{2}$ on the LlatpA gene and ATPase were inhibited by inhibitors of NO. The transcription levels of the cyclin-dependent kinase B decreased when $\mathrm{H}_{2}$ was used together with cPTIO, L-NAME, and $\mathrm{NaN}_{3}$, respectively [15]. It was suggested that NO may act as a signaling molecule involved in $\mathrm{H}_{2}$ to increase the expression of the LlatpA gene and the activity of ATPase. All of these results were consistent with the expression of AtpA protein. Taken together, $\mathrm{H}_{2}$ may play its positive role in the expression of the LlatpA gene and the activity of ATPase by regulating endogenous NO.

The results of transcriptional level and biochemical level analysis were consistent with the results of AtpA protein expression, suggesting that the involvement of $\mathrm{NO}$ in the $\mathrm{H}_{2}$-promoted vase life of cut lilies may be through regulation of the expression of AtpA protein. Since AtpA is a protein related to photosynthesis, and ATPase plays significant roles in photosynthesis-dependent membrane hyperpolarization and energy transfer [37], in the next study, the chlorophyll fluorescence parameters and photosynthetic parameters were determined to further validate the effects of the ATP protein on $\mathrm{NO}$ and $\mathrm{H}_{2}$ co-regulated postharvest preservation at the physiological level. We found that exogenous $\mathrm{H}_{2}$ could increase the value of $\mathrm{Fv} / \mathrm{Fm}$, $\Phi P S I I$, and qP. A previous study also found that exogenous $\mathrm{H}_{2}$ could significantly alleviate high light induced-damage to PSII [38]. In this study, proteomics analysis suggested that the expression of AtpA was up-regulated by $\mathrm{H}_{2}$. Therefore, $\mathrm{H}_{2}$ played positive roles in enhancing the light energy conversion efficiency of PSII, possibly by regulating the expression of AtpA protein. Exogenous NO could alleviate paraquat-induced decline of Fv/Fm [39]. Exogenous NO also could significantly increase $\mathrm{Fv} / \mathrm{Fm}$, and thereby the toxic effects of arsenic (As) on photosynthesis were alleviated in Luffa seedlings [40]. The exogenous NO could decrease qP to inhibit the electron transport rate (ETR) [41]. In this study, the ratio of Fv/Fm was increased by NO. However, exogenous NO did not significantly change the values of $\Phi P S I I$ and qP, suggesting that NO had no obvious role in the capture and distribution of light energy. Exogenous NO could remarkably alleviate the inhibition of Fv/Fm induced by chilling stress, while inhibitors of NO could reduce Fv/Fm, ФPSII, and qP [42]. Our data also revealed that the positive effects of $\mathrm{H}_{2}$ on Fv / Fm, ФPSII, and qP were inhibited by inhibitors of NO. This result was consistent with the result that inhibitors of NO inhibited the positive effects of $\mathrm{H}_{2}$ on the expression of the AtpA protein. Thus, the involvement of $\mathrm{NO}$ in the $\mathrm{H}_{2}$-regulated electron transport of PSII may be by regulating AtpA protein. Photosynthesis leads to the storage of 
solar energy in organic compounds. As a key enzyme related to photosynthesis, AtpA protein may affect photosynthesis efficiency [43]. Here, the results of photosynthetic analysis showed that Pn and Gs were increased by exogenous $\mathrm{H}_{2}$ or $\mathrm{NO}$, but the value of $\mathrm{Ci}$ decreased. The above results were consistent with the proteomics analysis, indicating that $\mathrm{H}_{2}$ enhanced photosynthesis by regulating the expression of AtpA protein. Exogenous $\mathrm{H}_{2}$ could also increase the $\mathrm{Pn}$ in a concentration-dependent manner in maize seedlings [38]. Exogenous NO effectively inhibited the decrease in Pn as a result of non-stomatal factors under acid rain stress [44]. These results suggested that $\mathrm{NO}$ and $\mathrm{H}_{2}$ played a positive role in improving the photosynthetic performance of cut lily leaves. Chen et al. (2014) [45] reported that the Pn of transgenic and wild-type rice plants was significantly increased by NO, while the effect of $\mathrm{NO}$ on the Pn was inhibited by an NO scavenger. The positive effect of $\mathrm{H}_{2}$ on alleviating the Al-induced inhibition of alfalfa root growth was inhibited by cPTIO (a scavenger of NO) and tungstate [16]. In the present study, the effect of $\mathrm{H}_{2}$ on Pn and Gs were decreased by inhibitors of NO. However, the $\mathrm{Ci}$ was increased when the roles of $\mathrm{H}_{2}$ were inhibited by $\mathrm{NO}$ inhibitors. This may be due to the positive relationship between intercellular $\mathrm{CO}_{2}$ concentration (Ci) and net photosynthetic rate (Pn) under stomatal opening. Proteomics analysis also showed that the positive effect of $\mathrm{H}_{2}$ on improving the expression of AtpA protein was inhibited by NO inhibitors. Therefore, the involvement of $\mathrm{NO}$ in $\mathrm{H}_{2}$-regulated photosynthesis may be through regulating the expression of AtpA protein.

In conclusion, exogenous $\mathrm{H}_{2}$ or $\mathrm{NO}$ significantly promoted the vase life and quality of cut lilies, and NO might play an important role in the $\mathrm{H}_{2}$-improved postharvest freshness of cut lilies. Additionally, $\mathrm{H}_{2}$ also significantly regulated the expression of AtpA protein and the activity ATPase, as well as photosynthesis in the postharvest freshness of cut lilies (Figure 8). Interestingly, NO may be involved in this process. Collectively, our results also revealed that NO was involved in the $\mathrm{H}_{2}$-enhanced shelf-life and quality of cut lilies, possibly through regulating the expression of the photosynthesis-related AtpA.

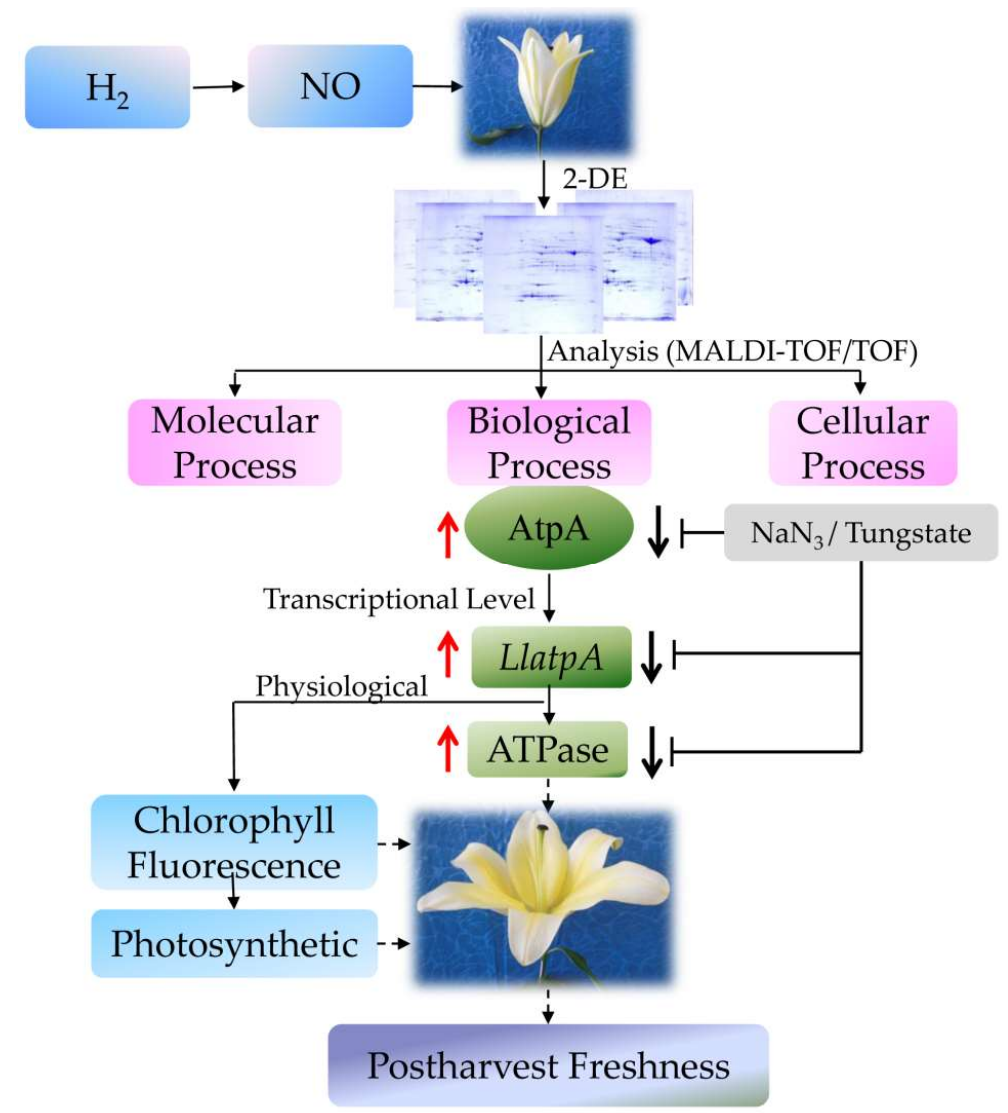

Figure 8. Schematic diagram of key proteins during nitric oxide-hydrogen gas-improved postharvest freshness in cut lily by comparative proteomic analysis. 


\section{Materials and Methods}

\subsection{Plant Material and Treatments}

Cut lily (Lilium "Manissa") flowers with a single green bud and similar flowering degree were obtained from a commercial grower (Qianxi Florist, Lanzhou, China) and transferred rapidly to the laboratory. Flowers were held in water for $12 \mathrm{~h}$ and then cut under water to a length of $45 \mathrm{~cm}$ and every flower having five leaves on the top was kept to provide homogenous samples. Finally, the flowers were inserted into $1 \mathrm{~L}$ of treatment solution: distilled water (the control), 1\% hydrogen-rich water (HRW, the preparation of HRW was based on the method of Zhu et al. [20]), $150 \mu \mathrm{M}$ sodium nitroprusside (SNP, a donor of NO), $1 \%$ HRW plus NO inhibitors $50 \mu \mathrm{M}$ sodium azide $\left(\mathrm{NaN}_{3}\right)$ or $100 \mu \mathrm{M}$ tungstate. The above chemicals were purchased from Sigma-Aldrich (St Louis, MO, USA) except for tungstate (tungstate was provided from Shanghai Zhaoyun chemical Co., Ltd., Shanghai, China). The treatment solution was exchanged every day at regulating time. Furthermore, each treatment was conducted in three replicates, with each replication including five cut flowers. The laboratory was maintained at $25 \pm 3{ }^{\circ} \mathrm{C}, 60 \% \pm 5 \%$ relative humidity, and $15 \mu \mathrm{mol} \cdot \mathrm{m}^{-2} \cdot \mathrm{s}^{-1}$ photons irradiance.

\subsection{Determination of Vase Life and Maximum Flower Diameter}

The vase life of cut lily flowers was determined according to time beginning on the first day when flowers were inserted in the vase solution. The vase life was considered to the termination when the flower was wilted. A Vernier caliper was used to measure the maximum flower diameter, which is the maximum distance between buds and petals. The cross method was conducted to measure the maximum flower diameter. After treatment, the maximum flower diameters were measured and recorded every day.

\subsection{Determination of the Rate of Fresh Weight Change}

The fresh weight of each flower before treatment was measured using an electronic balance and recorded as $W_{0}\left(W_{0}\right.$ is the fresh weight of the cut lilies at the first day). Then, the water at the base of the flower stem was blotted with filter paper and its fresh weight was measured. The value was recorded as $W_{\mathrm{d}}\left(W_{\mathrm{d}}\right.$ is the fresh weight of the cut lilies at $d=1,2,3 \ldots$ days). The rate of fresh weight change was calculated according to the formula: $\left[\left(W_{\mathrm{d}}-W_{0}\right) / W_{0}\right] \times 100$.

\subsection{Protein Extraction}

Three biological replicates were performed in the comparative proteomic analysis. The sample of $2 \mathrm{~g}$ cut lily leaves was used to extract protein in the eighth day of treatment. Each sample was ground to a fine powder with $0.04 \mathrm{~g}$ polyvingypyrrolidone (PVPP) in liquid nitrogen in a pre-cooled mortar. The powders were transferred into six $2 \mathrm{~mL}$ tubes. To each tube was added ice-cold trichloroacetic acid (TCA)/acetone (containing 10\% (v/v) TCA and 0.07\% (v/v) $\beta$-mercaptoethanol ( $\beta$-ME)). Samples were mixed with a vortex and placed in a freezer at $-20{ }^{\circ} \mathrm{C}$ overnight. The next day, the pellet was centrifuged at $20,000 \times g$ for $30 \mathrm{~min}$ at $4{ }^{\circ} \mathrm{C}$. Two milliliters of $100 \%(v / v)$ pre-cooled acetone (containing $0.07 \% \beta-\mathrm{ME}$ ) was added, mixed with a vortex and placed at $-20{ }^{\circ} \mathrm{C}$ for $1 \mathrm{~h}$, centrifuging at $20,000 \times g$ for $20 \mathrm{~min}$ at $4{ }^{\circ} \mathrm{C}$ and discarding the supernatant. Then, the step was repeated again. Two milliliters of $80 \%(v / v)$ pre-cooled acetone (containing $0.07 \% \beta-\mathrm{ME}$ ) was added, mixed by vortex and placed at $-20{ }^{\circ} \mathrm{C}$ for $30 \mathrm{~min}$, centrifuged at $20,000 \times \mathrm{g}$ for $15 \mathrm{~min}$ at $4{ }^{\circ} \mathrm{C}$, and the supernatant was discarded. Then, the step was repeated twice. The pellet was placed in a $2 \mathrm{~mL}$ centrifuge tube precooled with liquid nitrogen and placed in an in situ ordinary type freeze dryer (Scientz-10ND, Ningbo Xinzhi Biotechnology Co., Ltd., Ningbo, China) to dry to a white powder. A certain amount of $7 \mathrm{M}$ protein lysate containing DL-dithiothreitol (DTT) was added and cracked at room temperature for $2 \mathrm{~h}$, mixed by vortex one time per $30 \mathrm{~min}$ during cracking and centrifuged at $20,000 \times \mathrm{g}$ for $30 \mathrm{~min}$ at $4{ }^{\circ} \mathrm{C}$. The supernatant was the total protein of lily leaves. The resulting protein was stored at $-80{ }^{\circ} \mathrm{C}$ for next 
use. The protein concentration was determined according to the method described by Bradford assay (Bio-Rad, Hercules, CA, USA).

\subsection{Two-Dimensional Electrophoresis (2-DE) and Gel Image Analysis}

For two-dimensional electrophoresis (2-DE), a total of $0.8 \mathrm{mg}$ protein was first subjected to isoelectric focusing (IEF) and separated by two-dimensional SDS-PAGE. First-dimension IEF was done using pH 4-7 NL IPG strips (ReadyStrip, $17 \mathrm{~cm}$, BioRad, USA). The strips were rehydrated in a rehydration solution (7 M urea, $2 \mathrm{M}$ thiourea, 4\% CHAPS, $65 \mathrm{mM}$ DTT, 0.2\% ( $w / v)$ Bio-Lyte, and $0.001 \%$ bromophenol blue) containing the protein sample for $12 \mathrm{~h}$ at room temperature. IEF was conducted in a Protean ${ }^{\circledR}$ IEF Cell (Bio-Rad) at $20^{\circ} \mathrm{C}$, and the voltage was set as $50 \mathrm{~V}$ for $14 \mathrm{~h}, 250 \mathrm{~V}$ for $3 \mathrm{~h}, 1000 \mathrm{~V}$ for $5 \mathrm{~h}, 9000 \mathrm{~V}$ for $5 \mathrm{~h}$, and $9000 \mathrm{~V}$ until maximum $90,000 \mathrm{Vh}$, then under $500 \mathrm{~V}$ run for $24 \mathrm{~h}$. After first-dimension IEF, the strips were equilibrated instantly for $15 \mathrm{~min}$ in equilibration buffer I (6 M urea, $2 \%(w / v)$ SDS, $0.375 \mathrm{M}$ Tris- $\mathrm{HCl}(\mathrm{pH} 8.8), 20 \%(v / v)$ glycerol, $2 \%(w / v)$ DTT). Then, $5 \mathrm{~mL}$ equilibration buffer II (6 M urea, $2 \%(w / v)$ SDS, $0.375 \mathrm{M}$ Tris- $\mathrm{HCl}(\mathrm{pH} 8.8), 20 \%(v / v)$ glycerol, $2.5 \%(w / v)$ iodoacetamide) was added and incubated for $15 \mathrm{~min}$. Second dimension SDS-PAGE was conducted in $12 \%(v / v)$ polyacrylamide-SDS gel (Protean ${ }^{\circledR}$ Plus Dodeca Cell, Bio-Rad). After electrophoresis, the gels were stained with Coomassie Brilliant Blue (Bio-Rad). Stained 2-DE gels were scanned with a GS-800 Calibrated Densitometer (Bio-Rad), and data were analyzed by PDQuest software version 8.0 (Bio-Rad) as described by the manufacturer. The spots were automatically detected by the software and then subjected to careful manual editing and confirmation. Each spot of the standard gel accorded the following criteria: it was present in at least two of the three gels and was qualitatively consistent in size and shape in the replicate gels. The relative volume of each spot was assumed to represent the expression level of its protein. The volume of each well-separated spot was compared between control and different treatments to identify differentially accumulated protein spots. A spot abundance ratio of greater than $1.5(p<0.05)$ (a spot present uniquely or present in two-fold abundance in one sample relative to the other) was used as the threshold for a protein being differentially accumulated in subsequent studies. Every treatment was done with three biological replicates.

\subsection{Protein Identification and Database Searching}

Protein spots that appeared as differentially expressed between the control and treatment samples were excised from the gels and digested with trypsin (Promega, Madison, WI, USA), based upon the procedure described by Liu et al. [46]. MS and tandem mass spectrometry (MS/MS) data for protein identification were obtained by using a matrix-assisted laser desorption ionization time-of-flight (MALDI-TOF/TOF) instrument (4800 Plus MALDI TOF/TOFTM Analyzer; AB SCIEX, Framingham, MA, USA), as previously described by Sheffield et al. [47]. The MS/MS spectra searches were submitted to the NCBI database (http://www.ncbi.nlm.nih.gov) downloaded on 9 January 2017 (15,653 sequences) and Uniprot database (http:/ / www.uniprot.org/) downloaded on 21 September 2016 (3,887,742 sequences) to identify proteins in the MASCOT (version 2.2, Matrix Science, London, UK) search engine using the following search parameters: MS tolerance of $50 \mathrm{ppm}$, MS/MS tolerance of $0.5 \mathrm{Da}$, peptide molecular mass ranging from 400 to $4000 \mathrm{Da}$, with one missing cleavage site, fixed modifications of carbamidomethyl (Cys) and variable modifications of oxidation (Met). The Percolator algorithm was used to estimate the false discovery rate (FDR) based on $p$-value, and only peptides at the $99 \%$ confidence level were counted as the identified protein. Proteins were considered as identified when one protein had to contain at least two peptides and when average of fold change was $\geq 1.5$ in the experimentally treated groups compared to the control group.

\subsection{Quantitative RT-PCR ( $q R T-P C R)$ Analyses}

After 8 days of treatment, $1 \mathrm{~g}$ of the cut lily leaves was ground to a powder in liquid nitrogen and the total RNA was abstracted using TaKaRa MiniBEST plant RNA extraction kit (Takara Bio 
Inc, Kusatsu, Shiga, Japan) according to the manufacturer's instructions. For these samples, $1 \mu \mathrm{g}$ of total RNA was converted to cDNA using PrimeScript RT Master Mix kit (Takara Bio Inc, Kusatsu, Shiga, Japan) according to the manufacturer's instructions. Quantitative RT-PCR was conducted with SYBR ${ }^{\circledR}$ Premix Ex Taq ${ }^{\text {TM }}$ II (Takara Bio Inc, Kusatsu, Shiga, Japan) and LightCycler ${ }^{\circledR 96}$ (Roche Applied Science, Mannheim, Germany) automated PCR system using two-step cycling conditions of $95^{\circ} \mathrm{C}$ pre-degeneration for $30 \mathrm{~s}$, followed by 40 cycles of $95^{\circ} \mathrm{C}$ for $5 \mathrm{~s}$, and then annealing at $60{ }^{\circ} \mathrm{C}$ for $20 \mathrm{~s}$. The reaction mixture $(20 \mu \mathrm{L})$ contained $1 \mu \mathrm{L}$ of cDNA solution and primers at a concentration of $10 \mu \mathrm{M}$ each. The lily gene actin (JX826390) was used as a reference for calculating relative transcript abundance. The primers of actin were: forward (5'-TGCTGGATTCTGGTGATGGT- $3^{\prime}$ ) and reverse (5'-TCCCGTTCAGCTGTAGTTGT-3'). The CDS of ATP synthase CF1 alpha subunit (AtpA) was acquired according to accession no. by NCBI. The atpA gene Lilium "Manissa" was named the $\operatorname{Llatp} A$ gene. The LlatpA gene-specific primers were designed based on the cDNA sequences. The primers of LlatpA were: forward (5'-AAGCTTGTGCCTGTTTGGAG-3') and reverse (5'-AACGGCAGATTCACCTGCTA-3'). The method of comparative Ct $\left(2^{-\Delta \Delta C t}\right)$ [48] was used to calibrate the relative quantification of RNA expression. Each sample was set three biological replicates.

\subsection{Determination of ATP Synthase Activity}

A $1 \mathrm{~g}$ sample of the cut lily leaves was ground with a crude enzyme extracting solution $(2.75 \mathrm{~mL}$ $\beta$-mercaptoethanol and $0.688 \mathrm{~g}$ EDTA- $\mathrm{Na}_{2}$, volume fixed to $1 \mathrm{~L}$ using $20 \mathrm{mmol} / \mathrm{L}$ Tris- $\mathrm{HCl}$ ) to form a slurry. The slurry was filtered through four layers of gauze. Then, $1.5 \mathrm{~mL}$ of the filtrate was centrifuged at a speed of $12,000 \times \mathrm{g}$ at $4{ }^{\circ} \mathrm{C}$ for $10 \mathrm{~min}$. Subsequently, $100 \mu \mathrm{L}$ supernatant was added in $200 \mu \mathrm{L}$ of the reaction solution $\left(0.5448 \mathrm{~g}\right.$ ATP-Na and $0.6517 \mathrm{~g} \mathrm{MgCl}_{2} \cdot 6 \mathrm{H}_{2} \mathrm{O}$ were fixed to a volume of $300 \mathrm{~mL}$ using a $20 \mathrm{mmol} / \mathrm{L}$ maleic acid buffer) and incubated for $30 \mathrm{~min}$ at $38^{\circ} \mathrm{C}$. The reaction was terminated by $200 \mu \mathrm{L}$ TCA. Finally, $1.5 \mathrm{~mL}$ phosphorus reagent $\left(6 \mathrm{M} \mathrm{H}_{2} \mathrm{SO}_{4}\right.$ : distilled water: $2.5 \%$ ammonium molybdate aqueous solution: ascorbic acid $=1: 2: 1: 1)$ was added to the reaction to enact a color reaction for $20 \mathrm{~min}$ at $45{ }^{\circ} \mathrm{C}$. After finishing the color reaction, $3 \mathrm{~mL}$ distilled water was added to measure the OD value at $660 \mathrm{~nm}$ using a UV spectrophotometer (UV-2800A, Unico ${ }^{\circledR}$ (Shanghai) Instrument Co., Ltd., Shanghai, China). The inorganic phosphorus content was calculated according to the $\mathrm{OD}_{660}$ and the standard curve that prepared with $\mathrm{KH}_{2} \mathrm{PO}_{3}$ at different concentrations was: $y=8.235 x-0.0859$, $R^{2}=0.9984$. ATPase activity was calculated and the unit was $\left.\mu \mathrm{mol}(\mathrm{Pi}) \times(\mathrm{mg}(\mathrm{chl}) \mathrm{h})^{-1}\right)$.

\subsection{Determination of Chlorophyll Fluorescence and Photosynthetic Parameters}

Chlorophyll fluorescence parameters were investigated using an Imaging-PAM Chlorophyll Fluorometer (Walz, Effeltrich, Germany) at 2, 4, 6, 8, and 10 days after treatment. Before measurement, the cut lily leaves were kept in darkness for $30 \mathrm{~min}$ to allow all reaction centers to open. The maximum quantum yield of PSII $(\mathrm{Fv} / \mathrm{Fm}=(\mathrm{Fm}-\mathrm{Fo}) / \mathrm{Fm})$ and the effective quantum yield of PSII $(\Phi P S I I)\left[\Phi P S I I=\left(F^{\prime}-\mathrm{Fs}\right) / \mathrm{Fm}^{\prime}\right]$ was calculated according to Genty et al. [49]. Photochemical quenching $(\mathrm{qP})\left[\mathrm{qP}=\left(\mathrm{Fm}^{\prime}-\mathrm{Fs}\right) /\left(\mathrm{Fm}^{\prime}-\mathrm{Fo}^{\prime}\right)\right]$ was calculated according to Van Kooten and Snel (1990) [50]. Photosynthetic parameters were measured using a CIRAS-2 Portable Photosynthesis and Chlorophyll Fluorescence System (PP Systems Ltd., Hitchin, Herts, UK) at a photon irradiance of $1500 \mathrm{Lmol} \mathrm{m}^{-2} \mathrm{~s}^{-1}$. Three plants in each treatment were randomly selected for gas exchange measurement at 9:00 to 11:00 a.m. on a sunny morning at 2, 4, 6, 8, and 10 days after treatment. Net photosynthetic rate (Pn), transpiration rate (Tr), stomatal conductance (Gs), and intercellular $\mathrm{CO}_{2}$ concentration $(\mathrm{Ci})$ were recorded.

\subsection{Statistical Analysis}

Values are means $\pm \mathrm{SE}$ of three various experiments with three replicated measurements. Multiple comparisons were performed using Duncan's multiple range test to determine the significance of the results between different treatments at the $p<0.05$ level. The data analysis was conducted using the software SPSS 22.0 (SPSS Inc., Chicago, IL, USA). 
Supplementary Materials: Supplementary materials can be found at http:/ / www.mdpi.com/1422-0067/19/12/ 3955/s1.

Author Contributions: W.L. conceived the research idea and designed the experiment. J.H., J.Z., H.F., B.W., and Z.M. conducted the experiments. J.H., D.H., and C.W. finished the data analysis. J.H. prepared the manuscript. W.L. revised the manuscript. All the authors read and approved the submission of the manuscript.

Funding: This research was founded by Discipline Construction Funds for Horticulture, Gansu Agricultural University, China (GAU-XKJS-2018-228 ), the National Natural Science Foundation of China (31860568, 31560563 and 31160398), the Post Doctoral Foundation of China (20100470887 and 2012T50828), the Research Fund of Higher Education of Gansu, China (2018C-14), Scientific Research Foundation for the Yong Graduate Supervisor of Gansu Agricultural University in Lanzhou China (GAU-QNDS-201709) and Feitian and Fuxi Excellent Talents in Gansu Agricultural University.

Conflicts of Interest: The authors declare no conflict of interest.

$\begin{array}{ll}\text { Abbreviations } \\ \text { AtpA } & \text { ATP synthase } \mathrm{CF} 1 \text { alpha subunit (chloroplast) } \\ \mathrm{Ci} & \text { intercellular } \mathrm{CO}_{2} \text { concentration } \\ \mathrm{DTT} & \text { DL-dithiothreitol } \\ \mathrm{Fv} / \mathrm{Fm} & \text { the maximum quantum yield of PSII } \\ \mathrm{Gs} & \text { stomatal conductance } \\ \mathrm{HRW} & \text { hydrogen-rich water } \\ \mathrm{Pn} & \text { net photosynthetic rate } \\ \text { qP } & \text { photochemical quenching } \\ \mathrm{SNP} & \text { sodium nitroprusside } \\ \text { TCA } & \text { trichloroacetic acid } \\ \mathrm{Tr} & \text { transpiration rate } \\ 2-\mathrm{DE} & \text { two-dimensional electrophoresis } \\ \beta-\mathrm{ME} & \beta \text {-mercaptoethanol } \\ \text { ФPSII } & \text { the effective quantum yield of PSII }\end{array}$

\section{References}

1. Li, C.X.; Gong, T.Y.; Bian, B.T.; Liao, W.B. Roles of hydrogen gas in plants: A review. Funct. Plant Biol. 2018, 45, 783-792. [CrossRef]

2. Zhao, X.Q.; Chen, Q.H.; Wang, Y.M.; Shen, Z.G.; Shen, W.B.; Xu, X.M. Hydrogen-rich water induces aluminum tolerance in maize seedlings by enhancing antioxidant capacities and nutrient homeostasis. Ecotoxicol. Environ. Saf. 2017, 144, 369-379. [CrossRef] [PubMed]

3. Cui, W.T.; Fang, P.; Zhu, K.K.; Mao, Y.; Gao, C.Y.; Xie, Y.J.; Wang, J.; Shen, W.B. Hydrogen-rich water confers plant tolerance to mercury toxicity in alfalfa seedlings. Ecotoxicol. Environ. Saf. 2014, 105, 103-111. [CrossRef] [PubMed]

4. Su, N.N.; Wu, Q.; Liu, Y.Y.; Cai, J.T.; Shen, W.B.; Xia, K.; Cui, J. Hydrogen-rich water reestablishes ROS homeostasis but exerts differential effects on anthocyanin synthesis in two varieties of radish sprouts under UV-A irradiation. J. Agr. Food Chem. 2014, 62, 6454-6462. [CrossRef] [PubMed]

5. Cao, Z.Y.; Duan, X.L.; Yao, P.; Cui, W.T.; Cheng, D.; Zhang, J.; Jin, Q.J.; Chen, J.; Dai, T.S.; et al. Hydrogen gas is involved in auxin-induced lateral root formation by modulating nitric oxide synthesis. Int. J. Mol. Sci. 2017, 18, 2084. [CrossRef] [PubMed]

6. Lin, Y.T.; Zhang, W.; Qi, F.; Cui, W.T.; Xie, Y.J.; Shen, W.B. Hydrogen-rich water regulates cucumber adventitious root development in a heme oxygenase-1/carbon monoxide-dependent manner. J. Plant Physiol. 2014, 171, 1-8. [CrossRef] [PubMed]

7. Hu, H.L.; Li, P.X.; Wang, Y.N.; Gu, R.X. Hydrogen-rich water delays postharvest ripening and senescence of kiwifruit. Food Chem. 2014, 156, 100. [CrossRef] [PubMed]

8. Ren, P.J.; Jin, X.; Liao, W.B.; Wang, M.; Niu, L.J.; Li, X.P.; Zhu, Y.C. Effect of hydrogen-rich water on vase life and quality in cut lily and rose flowers. Hortic. Environ. Biotechnol. 2017, 58, 576-584. [CrossRef]

9. Manjunatha1, G.; Lokesh, V.; Neelwarne, B.; Singh, Z.; Gupta, K.J. Nitric oxide applications for quality enhancement of horticulture produce. Jules Janick. Hortic. Rev. 2014, 42, 121-156. [CrossRef] 
10. Shabaniana, S.; Esfahania, M.N.; Karamian, R.; Tran, L.S.P. Physiological and biochemical modifications by postharvest treatment with sodium nitroprusside extend vase life of cut flowers of two gerbera cultivars. Postharvest Biol. Technol. 2018, 137, 1-8. [CrossRef]

11. Dwivedic, S.K.; Aroraa, A.; Singha, V.P.; Sairama, R.; Bhattacharya, R.C. Effect of sodium nitroprusside on differential activity of antioxidants and expression of SAGs in relation to vase life of gladiolus cut flowers. Sci. Hortic. 2016, 210, 158-165. [CrossRef]

12. Zeng, C.L.; Liu, L.; Xu, G.Q. The physiological responses of carnation cut flowers to exogenous nitric oxide. Sci. Hortic. 2011, 127, 424-430. [CrossRef]

13. Liao, W.B.; Zhang, M.L.; Yu, J.H. Role of nitric oxide in delaying senescence of cut rose flowers and its interaction with ethylene. Sci. Hortic. 2013, 155, 30-38. [CrossRef]

14. Xie, Y.J.; Mao, Y.; Zhang, W.; Lai, D.W.; Wang, Q.Y.; Shen, W.B. Reactive oxygen species-dependent nitric oxide production contributes to hydrogen-promoted stomatal closure in Arabidopsis. Plant Physiol. 2014, 165, 759-773. [CrossRef] [PubMed]

15. Zhu, Y.C.; Liao, W.B.; Niu, L.J.; Wang, M.; Ma, Z.J. Nitric oxide is involved in hydrogen gas-induced cell cycle activation during adventitious root formation in cucumber. BMC Plant Biol. 2016, 16, 146. [CrossRef] [PubMed]

16. Chen, M.; Cui, W.T.; Zhu, K.K.; Xie, Y.J.; Zhang, C.H.; Shen, W.B. Hydrogen-rich water alleviates aluminum-induced inhibition of root elongation in alfalfa via decreasing nitric oxide production. J. Hazard. Mater. 2014, 267, 40-47. [CrossRef]

17. Baudouin, E.; Hancock, J.T. Nitric oxide signaling in plants. Front. Plant Sci. 2014, 4, 553. [CrossRef] [PubMed]

18. Zhu, Y.C.; Liao, W.B. The metabolic constituent and rooting-related enzymes responses of marigold explants to hydrogen gas during adventitious root development. Theor. Exp. Plant Physiol. 2017, 29, 1-9. [CrossRef]

19. Hu, H.L.; Zhao, S.P.; Li, P.X.; Shen, W.B. Hydrogen gas prolongs the shelf life of kiwifruit by decreasing ethylene biosynthesis. Postharvest Biol. Technol. 2018, 135, 123-130. [CrossRef]

20. Zhu, Y.C.; Liao, W.B.; Wang, M.; Niu, L.J.; Xu, Q.Q.; Jin, X. Nitric oxide is required for hydrogen gas-induced adventitious root formation in cucumber. J. Plant Physiol. 2016, 195, 50. [CrossRef]

21. Liu, R.X.; Chen, S.M.; Jiang, J.F.; Zhu, L.; Zheng, C.; Han, S.; Gu, J.; Sun, j.; Wang, H.B.; Song, A.P.; Chen, F.D. Proteomic changes in the base of chrysanthemum cuttings during adventitious root formation. BMC Genom. 2013, 14, 919. [CrossRef] [PubMed]

22. Song, J.; Fan, L.; Hughes, T.; Palmer Campbell, L.; Li, L.; Li, X.H. Quantitative proteomic investigation on the effect of 1-methylcyclopropene treatments on postharvest quality of selected cut flowers. Acta Hortic. 2015, 1104, 311-318. [CrossRef]

23. Dai, C.; Cui, W.T.; Pan, J.C.; Xie, Y.J.; Wang, J.; Shen, W.B. Proteomic analysis provides insights into the molecular bases of hydrogen gas-induced cadmium resistance in Medicago sativa. J. Proteom. 2017, 152, 109-120. [CrossRef] [PubMed]

24. Kang, R.Y.; Zhang, L.; Jiang, L.; Yu, M.L.; Ma, R.J.; Yu, Z.F. Effect of postharvest nitric oxide treatment on the proteome of peach fruit during ripening. Postharvest Biol. Technol. 2016, 112, 277-289. [CrossRef]

25. Li, L.; Song, J.; Kalt, W.; Forney, C.; Tsao, R.; Pinto, D.; Pinto, D.; Chisholm, K.; Campbell, L.; Fillmore, S.; et al. Quantitative proteomic investigation employing stable isotope labeling by peptide dimethylation on proteins of strawberry fruit at different ripening stages. J. Proteom. 2013, 94, 219-239. [CrossRef] [PubMed]

26. Li, T.T.; Zhu, H.; Wu, Q.X.; Yang, C.W.; Duan, X.W.; Qu, H.X.; Yun, Z.; Jiang, Y.M. Comparative proteomic approaches to analysis of litchi pulp senescence after harvest. Food Res. Int. 2015, 78, 274-285. [CrossRef] [PubMed]

27. Hisabori, T.; Konno, H.; Ichimura, H.; Strotmann, H.; Bald, D. Molecular devices of chloroplast F1-ATP synthase for the regulation. BBA Bioenerg. 2002, 1555, 140-146. [CrossRef]

28. Wang, L.X.; Pan, D.Z.; Li, J.; Tan, F.L.; Hoffmann-Benning, S.; Liang, W.Y.; Chen, W. Proteomic analysis of changes in the Kandelia candel chloroplast proteins reveals pathways associated with salt tolerance. Plant Sci. 2015, 231, 159. [CrossRef]

29. Lee, C.; Rhee, J.K.; Kim, D.G.; Choi, Y.E. Proteomic study reveals photosynthesis as downstreams of both MAP kinase and cAMP signaling pathways in Chlamydomonas reinhardtii. Photosynthetica 2015, 53, 625-629. [CrossRef]

30. Wolfgang, J.; Nathan, N. ATP Synthase. Annu. Rev. Biochem. 2015, 84, 631-657. [CrossRef] 
31. Shao, H.; Cao, Q.; Tao, X.; Gu, Y.; Chang, M.; Huang, C.; Zhang, Y.; Feng, H. Cloning and characterization of ATP synthase CF1 $\alpha$ gene from sweet potato. Afr. J. Biotechnol. 2011, 10, 19035-19042. [CrossRef]

32. Shu, S.; Yuan, Y.H.; Chen, J.; Sun, J.; Zhang, W.H.; Tang, Y.Y.; Zhong, M.; Guo, S. The role of putrescine in the regulation of proteins and fatty acids of thylakoid membranes under salt stress. Sci. Rep. 2015, 5, 14390. [CrossRef] [PubMed]

33. Viale, A.; Vallejos, R.; Jagendorf, A.T. Hydrogen exchange into soluble spinach chloroplast coupling factor during heat activation of its ATPase. BBA-Bioenerg. 1981, 637, 496-503. [CrossRef]

34. He, W.X.; Xu, Y.; Tang, L.; Wei, Q.; Li, J.; Chen, F. Molecular cloning regulation of chilling-repressed gene atpA in Elumus sibiricus. Prog. Biochem. Biophys. 2005, 32, 67-74.

35. Zandonadi, D.B.; Santos, M.P.; Dobbss, L.B.; Olivares, F.L.; Canellas, L.P.; Binzel, M.L.; Okorokova-Façanha, A.L.; Façanha, A.R. Nitric oxide mediates humic acids-induced root development and plasma membrane H+-ATPase activation. Planta 2010, 231, 1025-1036. [CrossRef] [PubMed]

36. Zhang, Y.K.; Han, X.X.; Chen, X.L.; Jin, H.; Cui, X.M. Exogenous nitric oxide on antioxidative system and ATPase activities from tomato seedlings under copper stress. Sci. Hortic. 2009, 123, 217-223. [CrossRef]

37. Okumura, M.; Inoue, S.I.; Kuwata, K.; Kinoshita, T. Photosynthesis activates plasma membrane H+-ATPase via sugar accumulation in Arabidopsis leaves. Plant Physiol. 2016. [CrossRef] [PubMed]

38. Zhang, X.N.; Zhao, X.Q.; Wang, Z.Q.; Shen, W.B.; Xu, X.M. Protective effects of hydrogen-rich water on the photosynthetic apparatus of maize seedlings (Zea mays L.) as a result of an increase in antioxidant enzyme activities under high light stress. Plant Growth Regul. 2015, 77, 43-56. [CrossRef]

39. Cui, J.X.; Zhou, Y.H.; Ding, J.G.; Xia, X.J.; Shi, K.; Chen, S.C.; Asami, T.; Yu, J.Q. Role of nitric oxide in hydrogen peroxide-dependent induction of abiotic stress tolerance by brassinosteroids in cucumber. Plant Cell Environ. 2011, 34, 347. [CrossRef] [PubMed]

40. Singh, V.P.; Srivastava, P.K.; Prasad, S.M. Nitric oxide alleviates arsenic-induced toxic effects in ridged Luffa seedlings. Plant Physiol. Biochem. 2013, 71, 155-163. [CrossRef] [PubMed]

41. Wodala, B.; Deák, Z.; Vass, I.; Erdei, L. Nitric oxide modifies photosynthetic electron transport in pea leaves. Acta Biol. Szegediensis 2005, 49, 7-8.

42. Dong, N.G.; Li, Y.F.; Qi, J.X.; Chen, Y.H.; Hao, Y.B. Nitric oxide synthase-dependent nitric oxide production enhances chilling tolerance of walnut shoots in vitro via involvement chlorophyll fluorescence and other physiological parameter levels. Sci. Hortic. 2018, 230, 68-77. [CrossRef]

43. Spetea, C.; Schoefs Spetea, B. Solute transporters in plant thylakoid membranes: Key players during photosynthesis and light stress. Commun. Integr. Biol. 2010, 3, 122-129. [CrossRef]

44. Wang, T.; Yang, W.H.; Xie, Y.F.; Shi, D.W.; Ma, Y.L.; Sun, X. Effects of exogenous nitric oxide on the photosynthetic characteristics of bamboo (Indocalamus barbatus McClure) seedlings under acid rain stress. Plant Growth Regul. 2017, 82, 69-78. [CrossRef]

45. Chen, P.B.; Li, X.; Huo, K.; Wei, X.D.; Dai, C.C.; Lv, C.G. Promotion of photosynthesis in transgenic rice over-expressing of maize $\mathrm{C}_{4}$ phosphoenolpyruvate carboxylase gene by nitric oxide donors. J. Plant Physiol. 2014, 171, 458-466. [CrossRef] [PubMed]

46. Liu, S.J.; Gao, J.D.; Chen, Z.J.; Qiao, X.Y.; Huang, H.L.; Cui, B.Y.; Zhu, Q.F.; Dai, Z.; Wu, H.; Pan, Y.; Yang, C. Comparative proteomics reveals the physiological differences between winter tender shoots and spring tender shoots of a novel tea (Camellia sinensis L.) cultivar evergrowing in winter. BMC Plant Biol. 2017, 17, 206. [CrossRef] [PubMed]

47. Sheffield, J.; Taylor, N.; Fauquet, C.; Chen, S. The cassava (Manihot esculenta Crantz) root proteome: Protein identification and differential expression. Proteomics 2006, 6, 1588-1598. [CrossRef]

48. Livak, K.J.; Schmitgen, T.D. Analysis of relative gene expression data using real-time quantification PCR and the 2- $\Delta \Delta$ Ct method. Methods 2001, 25, 402-408. [CrossRef]

49. Genty, B.; Briantais, J.M.; Baker, N.R. The relationship between the quantum yield of photosynthetic electron transport and quenching of chlorophyll fluorescence. BBA-Gen. Subj. 1989, 990, 87-92. [CrossRef]

50. Van Kooten, O.; Snel, J.F.H. The use of chlorophyll fluorescence nomenclature in plant stress physiology. Photosynth. Res. 1990, 25, 147-150. [CrossRef]

(C) 2018 by the authors. Licensee MDPI, Basel, Switzerland. This article is an open access article distributed under the terms and conditions of the Creative Commons Attribution (CC BY) license (http:/ / creativecommons.org/licenses/by/4.0/). 